\title{
Coupling of Nitric Oxide and Release of Nitrous Oxide from Rare-Earth-Dinitrosyliron Complexes
}

\author{
Arun K. Bar, ${ }^{\dagger}$ María José Heras Ojea, ${ }^{\dagger}$ Jinkui Tang, ${ }^{\ddagger} *$ Richard A. Layfield ${ }^{\dagger * *}$ \\ ${ }^{\dagger}$ Department of Chemistry, School of Life Sciences, University of Sussex, Brighton, BN1 9QJ, U.K. \\ Changchun Institute of Applied Chemistry, Chinese Academy of Sciences, Renmin Street 5626, 130022 \\ Changchun, China
}

1. Synthesis details

S1-S3

2. IR, UV-vis, NMR and EPR spectra and GC-MS S4-S28

3. X-ray crystallography

S29-S37

4. Magnetic property measurements

S38-S44

5. References

S45

\section{Synthesis Details}

All manipulations were performed under an atmosphere of dry, oxygen-free argon, using either standard Schlenk techniques or an argon-filled glove box. Toluene and THF, and their deuterated analogues for NMR spectroscopy, were dried by refluxing over potassium and collected by distillation. All solvents were stored over activated $4 \AA$ molecular sieves or a potassium mirror and freeze-thaw degassed prior to use. The starting materials $\left[\mathrm{Cp}^{*}{ }_{2} \mathrm{M}\left(\mathrm{BPh}_{4}\right)\right] \quad(\mathrm{M}=\mathrm{Y}, \mathrm{Gd}),{ }^{1}, \mathrm{HL}^{\text {Mes }},{ }^{2}\left[\mathrm{Li}\left(\mathrm{L}^{\mathrm{Mes}}\right)\right],{ }^{2}[\mathrm{PPN}]\left[\mathrm{FeI}_{2}(\mathrm{NO})_{2}\right]^{3}$ and $\left[\mathrm{Bu}_{4} \mathrm{~N}\right]\left[\left(\mathrm{L}^{\mathrm{Dipp}}\right) \mathrm{Fe}(\mathrm{NO})_{2}\right]^{4}$ were prepared according to slight variations of literature procedures. The cyclopentadienyl iron(II) dicarbonyl dimer $\mathrm{Fp}_{2}$ was purchased from Sigma-Aldrich, and $\mathrm{K}$ [Fp] was synthesised by reduction with $\mathrm{KC}_{8}$ in thf. Elemental analyses were carried out at London Metropolitan University, U.K. Infrared spectra were recorded on neat material in an inert atmosphere using a Bruker Alpha FT-IR spectrometer. UV-Vis spectroscopic studies were carried out with Perkin-Elmer L-750 UV-Vis NIR instrument. ${ }^{1} \mathrm{H}$ NMR experiments were carried out on a Varian VNMR S400 spectrometer operating at $400 \mathrm{MHz}\left({ }^{1} \mathrm{H}\right)$ at $30{ }^{\circ} \mathrm{C}$ unless otherwise stated. Samples for X-band CW-EPR spectroscopy were prepared under argon and measured either as polycrystalline samples or frozen toluene solutions using a Bruker EMX EPR spectrometer using 4 mm o.d. quartz tubes.

Synthe sis of $\left[\left(\mathbf{L}^{\mathrm{Mes}}\right) \mathbf{F e}(\mathbf{N O})_{2}\right]$ : A solution of $\left[\mathrm{Li}\left(\mathrm{L}^{\mathrm{Mes}}\right)\right](4.125 \mathrm{~g}, 10 \mathrm{mmol})$ in $\mathrm{THF}(200 \mathrm{~mL})$ was cooled to $30^{\circ} \mathrm{C}$ and slowly added to a stirred solution of $[\mathrm{PPN}]\left[\mathrm{FeI}_{2}(\mathrm{NO})_{2}\right](9.08 \mathrm{~g}, 10 \mathrm{mmol})$ in THF $(100 \mathrm{~mL})$ at -30 ${ }^{\circ} \mathrm{C}$. Upon addition, the reaction mixture turned dark brown-grey and, after warming to room temperature and stirring for two hours, became black with concomitant formation of a white precipitate. The solvent was evaporated and the residue was extracted with pentane $(\sim 150 \mathrm{~mL})$. The pentane solution was concentrated to $\sim 15 \mathrm{~mL}$ and stored at $-42{ }^{\circ} \mathrm{C}$ for 12 hours, which resulted in the formation of black crystals. The crystals of 1a were collected and dried under reduced pressure. Yield: $3.37 \mathrm{~g}, 75 \%$. IR $\left(\mathrm{cm}^{-1}\right)$ : 3430, 3148, 3081-2731 (broad), 1830 (NO stretch), 1752 (NO stretch), 1687 (NO stretch), 1609 (NO stretch), 1540, 1517, 1502, 1474, 1438, 1368, 1291, 1289, 1260, 1226, 1197, 1147, 1099, 1021, 958, 932, 883, 860, 803, 754, 729, 677, 632, 567, 539. UV-vis (toluene, $\left.\lambda_{\max }, \mathrm{nm}\right): 340,390,553,640 .{ }^{1} \mathrm{H}$ NMR (toluene-D $\left.8, \mathrm{ppm}\right): 10.5(5 \mathrm{H}, \mathrm{b}$ ), 5.91-4.65 (24H, b). Evans NMR: $\mu_{\text {eff }}=1.658 \mu_{\mathrm{B}}$. Elemental analysis (\%) calcd. for $\mathrm{C}_{23} \mathrm{H}_{29} \mathrm{FeN}_{4} \mathrm{O}_{2}: \mathrm{C}, 61.48$; H, 6.51; N, 12.47. Found: C, 61.84; H, 6.59; N, 12.37 .

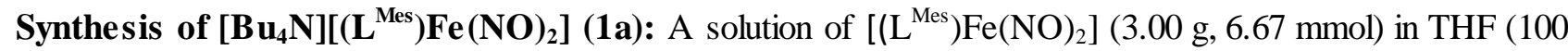
$\mathrm{mL})$ was added slowly to a stirred suspension of $\mathrm{KC}_{8}(2.256 \mathrm{~g}, 16.69 \mathrm{mmol})$ in $\mathrm{THF}(75 \mathrm{~mL})$ at $-70{ }^{\circ} \mathrm{C}$. Upon addition, the reaction mixture turned a brown-yellow colour. After complete, the reaction mixture was stirred at room temperature for six hours, at which point solid $\left[\mathrm{Bu}_{4} \mathrm{~N}\right]\left[\mathrm{PF}_{6}\right](3.88 \mathrm{~g}, 10 \mathrm{mmol})$ was added. The reaction was stirred for another two hours followed by filtration through porosity 3 frit packed with Celite. The filtrate was evaporated to dryness, which deposited a brown brown residue. The product was then extracted with toluene $(\sim 200 \mathrm{~mL})$ and filtered through glass micro-filter paper. The filtrate was then evaporated to dryness, washed twice with hexane and dried again, which produced pure 1a as brown-yellow 
crystals. Yield: $3.28 \mathrm{~g}, 71 \%$. Yellow, needle-like single crystals were grown by storing a saturated toluene solution at $-45{ }^{\circ} \mathrm{C}$. IR $\left(\mathrm{cm}^{-1}\right)$ : 3073, 3004-2802 (broad), 1759 (NO stretch), 1702 (NO stretch), 1623 (NO stretch), 1605 (NO stretch), 1560 (NO stretch), 1522, 1470-1370 (broad), 1318, 1261, 1220, 1196, 1178, 1146, 1094, 1056, 1017, 959, 937, 924, 883, 853, 793, 761, 736, 715, 695, 686, 660, 637, 603, 570, 544. UVvis (toluene, $\left.0.1 \mathrm{mM}, \lambda_{\max }, \mathrm{nm}\right): 340,580 .{ }^{1} \mathrm{H}$ NMR (toluene- $\left.\mathrm{D}_{8}, \mathrm{ppm}\right): 6.62(\mathrm{~s}, 4 \mathrm{H}, \mathrm{Ph}), 4.91(\mathrm{~s}, 1 \mathrm{H}$, NacNac-CH), 2.49 (s, 12H,o-Me), 2.28 (unresolved multiplet, 8H, ammonium- $\mathrm{CH}_{2}$ ), 1.98 (s, 6H, Me), 1.63 (s, 6H, p-Me), 0.89 (unresolved multiplet, $16 \mathrm{H}$, ammonium- $\mathrm{CH}_{2}$ ), 0.65 (unresolved multiplet, 12H, ammonium- $\left.\mathrm{CH}_{3}\right) .{ }^{13} \mathrm{C}$ NMR (benzene- $\left.\mathrm{D}_{6}, \delta / \mathrm{ppm}\right)$ : 161.35 (C, NacNac), 152.53 (CH, NacNac), $131.45(\mathrm{C}, \alpha-$ Mes), 129.69 (CH, $m$-Mes), 128.21 (C, o-Mes), 127.96 (C, $p$-Mes), $57.19\left(\mathrm{CH}_{2}, \alpha-{ }^{n} \mathrm{Bu}\right), 23.12\left(\mathrm{CH}_{2}, \beta-{ }^{n} \mathrm{Bu}\right)$, 22.13 (Me, NacNac), 20.74 (Me, $p$-Mes), $19.14\left(\mathrm{CH}_{2}, \gamma_{-}{ }^{n} \mathrm{Bu}\right), 13.37$ (Me, $\left.\delta{ }^{n} \mathrm{Bu}\right) . \quad$ Anal. Calcd for $\mathrm{C}_{39} \mathrm{H}_{65} \mathrm{FeN}_{5} \mathrm{O}_{2}$ : C, 67.71; H, 9.47; N, 10.12. Found: C, 67.57; H, 9.59; N, 10.17.

Synthesis of $\left[\left(\mathbf{C p}^{*}\right)_{2} \mathbf{Y}(\mathbf{O N})_{2} \mathbf{F e}\left(\mathbf{L}^{\text {Mes }}\right)\right]\left(\mathbf{2}_{\mathrm{Y}}\right)$ : A solution of $\mathbf{1 a}(500 \mathrm{mg}, 0.723 \mathrm{mmol})$ in toluene $(50 \mathrm{~mL})$ was slowly added to a suspension of $\left[\left(\mathrm{Cp}^{*}\right)_{2} \mathrm{Y}\left(\mathrm{BPh}_{4}\right)\right](495 \mathrm{mg}, 0.729 \mathrm{mmol})$ in toluene $(25 \mathrm{~mL})$ at room temperature, which immediately produced a dark-green with concomitant appearance of a gelatinous white precipitate. The reaction was stirred for two hours followed by filtration through glass micro-fibre filter paper, producing a dark-green solution. The solvent was evaporated under reduced pressure, and the residue was extracted with cold pentane and filtered through glass micro-fibre filter paper. The filtrate was evaporated slowly to dryness under reduced pressure, producing $\mathbf{2}_{\mathbf{Y}}$ as a green, polycrystalline material. Yield: $530 \mathrm{mg}, 91 \%$. Green, rod-like single crystals were grown by storing a saturated pentane solution at $45{ }^{\circ} \mathrm{C}$ overnight. IR $\left(\mathrm{cm}^{-1}\right): 3022-2757$ (broad), 2727, 1754 (NO stretch), 1684 (NO stretch), 1631 (NO stretch), 1609 (NO stretch), 1548 (NO stretch), 1534, 1493, 1446, 1394, 1373, 1253, 1225, 1199, 1147, 1018, 961, 878, 855, 828, 802, 750, 682, 592, 578, 569, 529, 494. UV-vis (toluene, $0.1 \mathrm{mM}, \lambda_{\max }, \mathrm{nm}$ ): 352,375 , 415, 597. ${ }^{1} \mathrm{H}$ NMR (toluene- $\left.\mathrm{D}_{8}, \delta / \mathrm{ppm}\right): 6.68$ (s, 4H, Ph), 5.59 (s, 1H, NacNac-CH), 2.17 (s, 6H, $p-\mathrm{Me}$ ), 2.04 (s, 12H, o-Me), 1.74 (s, 6H, Me), 1.66 (s, 30H, Cp*). ${ }^{13} \mathrm{C}$ NMR (benzene- $\left.\mathrm{D}_{6}, \delta / \mathrm{ppm}\right) 132.43$ (C, $\alpha-\mathrm{NacNac}$ ), 130.42 (CH, $\beta$-NacNac), 127.14 (C, overlapping $\alpha$-Mes, $m$-Mes), 126.95 (C, o-Mes), 126.75 (C, $p$-Mes), $118.54\left(\mathrm{C}, \mathrm{Cp}^{*}\right), 19.45(\mathrm{Me}, \mathrm{NacNac}), 16.62(\mathrm{Me}, p-\mathrm{Mes}), 9.28(\mathrm{Me}, \mathrm{Cp} *), 0.22(\mathrm{Me}, o$-Mes). Elemental analysis (\%) calcd. for $\mathrm{C}_{43} \mathrm{H}_{59} \mathrm{FeN}_{4} \mathrm{O}_{2} \mathrm{Y}$ : C 63.86; H 7.35; N 6.93. Found: C 63.75; H 7.41; 6.91 .

Synthesis of $\left[\left(\mathbf{C p}^{*}\right)_{2} \mathrm{Gd}(\mathrm{ON})_{2} \mathbf{F e}\left(\mathrm{L}^{\mathrm{Mes}}\right)\right]\left(2_{\mathrm{Gd}}\right)$ : this compound was synthesized using the same procedure described for $\mathbf{2}_{\mathbf{Y}}$ using $\mathbf{1 a}(500 \mathrm{mg}, 0.723 \mathrm{mmol})$ and $\left[\left(\mathrm{Cp}^{*}\right)_{2} \mathrm{Gd}\left(\mathrm{BPh}_{4}\right)\right](545 \mathrm{mg}, 0.73 \mathrm{mmol})$. Yield: 589 mg, $93 \%$. IR ( $\left.\mathrm{cm}^{-1}\right)$ : 3050-2767 (broad), 2723, 1754 (NO stretch), 1679 (NO stretch), 1629 (NO stretch), 1608 (NO stretch), 1534, 1493, 1444, 1373, 1383, 1254, 1199, 1147, 1101, 1061, 1019, 934, 878, 855, 830, 802, 750, 729, 706, 681, 652, 627, 591, 579, 569, 530, 511, 496. UV-vis (toluene, $0.1 \mathrm{mM}, \lambda_{\max }, \mathrm{nm}: 350$, 400, 590. Elemental analysis (\%) calcd. for $\mathrm{C}_{43} \mathrm{H}_{59} \mathrm{FeGdN}_{4} \mathrm{O}_{2}: \mathrm{C}, 58.89 ; \mathrm{H}, 6.78 ; \mathrm{N}, 6.39$. Found: C 59.05; $\mathrm{H}$ $6.76 ;$ N 6.49 .

Synthesis of $\left[\left(\mathbf{C p}^{*}\right)_{2} \mathbf{Y}(\mathbf{O N})_{2} \mathbf{F e}\left(\mathbf{L}^{\text {Dipp }}\right)\right]\left(\mathbf{3}_{\mathbf{Y}}\right)$ : A solution of $\mathbf{1 b}(750 \mathrm{mg}, 0.97 \mathrm{mmol})$ in toluene $(250 \mathrm{~mL})$ was added over 45 minutes to a stirred suspension of $\left[\left(\mathrm{Cp}^{*}\right)_{2} \mathrm{Y}\left(\mathrm{BPh}_{4}\right)\right](662 \mathrm{mg}, 0.98 \mathrm{mmol})$ in toluene $(200 \mathrm{~mL})$ at $-78^{\circ} \mathrm{C}$. The reaction mixture was vigorously stirred and then warmed slowly to room temperature and stirred for one hour. The green colour of the reaction mixture gradually darkened with concomitant appearance of gelatinous white precipitate. The mixture was then cooled to $0^{\circ} \mathrm{C}$ and filtered through a porosity 3 frit packed with Celite. The resulting dark green solution was evaporated to dryness, which produced a green residue which was extracted into pentane $(75 \mathrm{~mL})$ and filtered through a porosity 3 frit packed with Celite, leaving a green solution. The filtrate was slowly concentrated by evaporating the solvent to the point of incipient crystallization and then stored at $-72{ }^{\circ} \mathrm{C}$ for $1 \mathrm{~h}$. The nascent cold solution was decanted away and the residue was dried under reduced pressure to give $\mathbf{3}_{\mathbf{Y}}$. pentane as a green crystalline material. Yield: $699 \mathrm{mg}, 75 \%$. IR $\left(\mathrm{cm}^{-1}\right)$ : 3054, 2959, 2926, 2905, 2867, 2726, 1760 (NO stretch), 1721 (NO stretch), 1996 (NO stretch), 1648 (NO stretch), 1623 (NO stretch), 1552 (NO stretch), 1532, 1496, 1462, 1435, 1397, 1377, 1316, 1257, 1228, 1197, 1177, 1097, 1055, 1022, 969, 954, 935, 864, 850, 796, 763, 747, 729, 716, 701, 689, 629*, 585, 550, 522, 453. UV-Vis (toluene, $\left.0.1 \mathrm{mM}, \lambda_{\max }, \mathrm{nm}\right): 402,590 .{ }^{1} \mathrm{H}$ NMR $(293$ $\mathrm{K}$ toluene- $\left.d_{8}, \delta / \mathrm{ppm}, J / \mathrm{Hz}\right): 6.91\left(\mathrm{~m}, 6 \mathrm{H}, \mathrm{Ph},{ }^{3} \mathrm{~J}=4.6\right), 5.70(\mathrm{~s}, 1 \mathrm{H}, \mathrm{NacNac}-\mathrm{CH}), 3.10\left(\mathrm{~m}, 4 \mathrm{H},{ }^{\mathrm{i}} \mathrm{Pr}-\mathrm{CH},{ }^{3} J=\right.$ 6.8), 1.88 (s, 6H, Me), 1.66 (s, 30H, Cp*), 1.35 (d, 12H, ${ }^{\mathrm{i}} \mathrm{Pr}-\mathrm{Me},{ }^{3} \mathrm{~J}=6.8$ ), 1.13 (d, 12H, ${ }^{\mathrm{i}} \mathrm{Pr}-\mathrm{Me},{ }^{3} J=6.9$ ). Evans NMR: $\left(\mu_{\text {effif }}, \mu_{\mathrm{B}}\right)$ : 0. Elemental analysis $(\%)$ calcd. for $\mathrm{C}_{54} \mathrm{H}_{83} \mathrm{FeN}_{4} \mathrm{O}_{2} \mathrm{Y}$ : C 67.21; $\mathrm{H}$ 8.67; N 5.81; Found: C 66.98; H 8.61; N 5.91. 
Synthesis of $\left[\left(\mathrm{Cp}^{*}\right)_{2} \mathrm{Gd}(\mathrm{ON})_{2} \mathbf{F e}\left(\mathrm{L}^{\text {Dipp }}\right)\right]\left(\mathbf{3}_{\mathrm{Gd}}\right)$ : this compound was synthesized using the same procedure described for $\mathbf{3}_{\mathbf{Y}}$ using $\mathbf{1 b}(750 \mathrm{mg}, 0.97 \mathrm{mmol})$ and $\left[(\mathrm{Cp} *)_{2} \mathrm{Gd}\left(\mathrm{BPh}_{4}\right)\right](729 \mathrm{mg}, 0.98 \mathrm{mmol})$. Yield of $\mathbf{3}_{\mathrm{Gd}}$ pentane $725 \mathrm{mg}, 73 \%$. IR $\left(\mathrm{cm}^{-1}\right): 3059,3021,2958,2924,2907,2866,2728,1805\left(v_{\mathrm{NO}}\right), 1761\left(v_{\mathrm{NO}}\right)$, $1710\left(v_{\mathrm{NO}}\right), 1648\left(\mathrm{v}_{\mathrm{NO}}\right), 1623\left(\mathrm{v}_{\mathrm{NO}}\right), 1552\left(\mathrm{v}_{\mathrm{NO}}\right), 1531,1497,1461,1435,1399,1377,1316,1253,1228$, $1197,1177,1100,1055,1023,934,850,795,762,746,728,689,632,610,585,550,522,452$. UV-Vis (toluene, $0.1 \mathrm{mM}, \lambda_{\max }, \mathrm{nm}$ ): 405, 589. Elemental analysis (\%) calcd. for $\mathrm{C}_{54} \mathrm{H}_{83} \mathrm{FeN}_{4} \mathrm{O}_{2} \mathrm{Gd}: \mathrm{C} 62.76 ; \mathrm{H} \mathrm{8.10}$; N 5.42; Found: C 62.83; H 8.16; N 5.37.

Synthesis of $\left[(\mathbf{C p})_{2} \mathbf{Y O F e}\left(\mathbf{L}^{\text {Dipp }}\right)\right]\left(\mathbf{4}_{\mathbf{Y}}\right)$ : A solution of $\mathbf{3}_{\mathbf{Y}}(500 \mathrm{mg}, 0.52 \mathrm{mmol})$ in hexane $(75 \mathrm{~mL})$ was stirred at room temperature for five days, with occasional partial removal of the head space gas by applying a weak vacuum. The dark green solution slowly became brown-yellow and a yellow crystalline material began to precipitate after around three days. The volume of the solution was reduced to approximately $15 \mathrm{~mL}$ and stored at $0^{\circ} \mathrm{C}$ for several hours, which resulted in the formation of yellow crystals. The nascent solution was decanted and the crystalline material was washed with cold hexane $\left(-45^{\circ} \mathrm{C}, 2 \times 5 \mathrm{~mL}\right)$. The residue was dried under reduced pressure to obtain $\mathbf{4}_{\mathbf{Y}}$ as yellow crystals $(215 \mathrm{mg}, 49 \%)$. The washings and the filtrate were combined and stirred for another two days. Concentration of the reaction mixture and storing at $0^{\circ} \mathrm{C}$ yielded additional $(100 \mathrm{mg})$ of product. Overall isolated yield: $72 \%$. IR $\left(\mathrm{cm}^{-1}\right): 2957,2906,2860,1525,1486$, 1459, 1435, 1389, 1317, 1260, 1177, 1103, 1056, 1023, 933, 907, 856, 796, 764, 749, 716, 704, 660, 634, 594, 581, 530, 480, 431. UV-vis (toluene, $0.5 \mathrm{mM}, \lambda_{\max }, \mathrm{nm}$ ): $287,334,375 .{ }^{1} \mathrm{H}$ NMR (toluene-- $\mathrm{D}_{8}, \delta / \mathrm{ppm}$ ): $119.5(2 \mathrm{H}, p-\mathrm{Ph}), 63.0(6 \mathrm{H}, \mathrm{NacNac}-\mathrm{Me}), 12.1\left(30 \mathrm{H}, \mathrm{Cp}^{*}\right),-10.8\left(12 \mathrm{H},{ }^{\mathrm{i}} \mathrm{Pr}-\mathrm{Me}\right),-14.8(4 \mathrm{H}, o-\mathrm{Ph}),-53.5$ $(1 \mathrm{H}, \mathrm{NacNac}-\mathrm{CH}),-69.9\left(12 \mathrm{H},{ }^{\mathrm{i}} \mathrm{Pr}-\mathrm{Me}\right),-151.2\left(4 \mathrm{H},{ }^{\mathrm{i}} \mathrm{Pr}-\mathrm{CH}\right)$. Elemental analysis $(\%)$ calcd. for $\mathrm{C}_{49} \mathrm{H}_{71} \mathrm{FeN}_{2} \mathrm{OY}$ : C, 69.33; H, 8.43; N, 3.30. Found: C 69.38; H 8.41; N 3.31.

Synthesis of $\left[\left(\mathbf{C p}^{*}\right)_{2} \mathbf{G d O F e}\left(\mathrm{L}^{\mathrm{Dipp}}\right)\right]\left(\mathbf{4}_{\mathrm{Gd}}\right)$ : this compound was synthesized using the same procedure described for $\mathbf{4}_{\mathbf{Y}}$ using $\mathbf{3}_{\mathbf{G d}}$ (500 mg, $0.48 \mathrm{mmol}$ ), which resulted in $\mathbf{4}_{\mathbf{G d}}$ as yellow crystals $(345 \mathrm{mg}, 78 \%)$. IR $\left(\mathrm{cm}^{-1}\right): 2958,2922,2907,2866,1526,1487,1459,1435,1389,1342,1318,1282,1261,1230,1178,1104$, 1066, 1024, 934, 890, 855, 797, 761, 747, 634, 554, 517, 491, 436. UV-vis (toluene, $0.5 \mathrm{mM}, \lambda_{\max }, \mathrm{nm}$ ): 386 , 335, 376. Elemental analysis (\%) calcd. for $\mathrm{C}_{49} \mathrm{H}_{71} \mathrm{FeN}_{2} \mathrm{OGd}: \mathrm{C}, 64.17 ; \mathrm{H}, 7.80 ; \mathrm{N}, 3.05$. Found: $\mathrm{C} 64.29 ; \mathrm{H}$ $7.71 ; \mathrm{N} 3.09$. 


\section{$\underline{\text { IR, UV-vis and NMR spectra }}$}
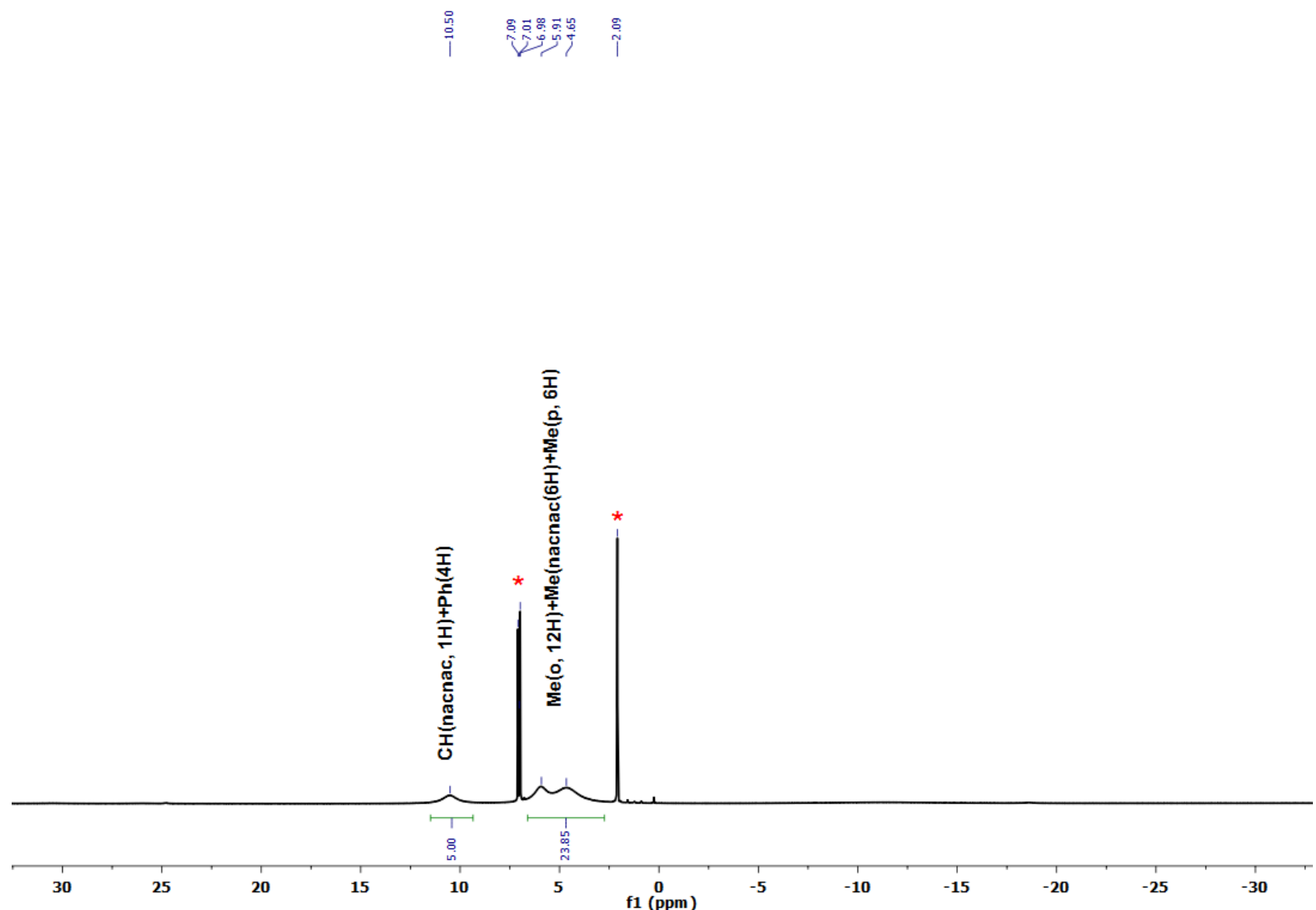

Figure S1. ${ }^{1} \mathrm{H}$ NMR spectrum of $\left[\left(\mathrm{L}^{\mathrm{Mes}}\right) \mathrm{Fe}(\mathrm{NO})_{2}\right]$ in toluene- $\mathrm{D}_{8}$ at $298 \mathrm{~K}$. The red asterisks correspond to residual solvent peaks. 


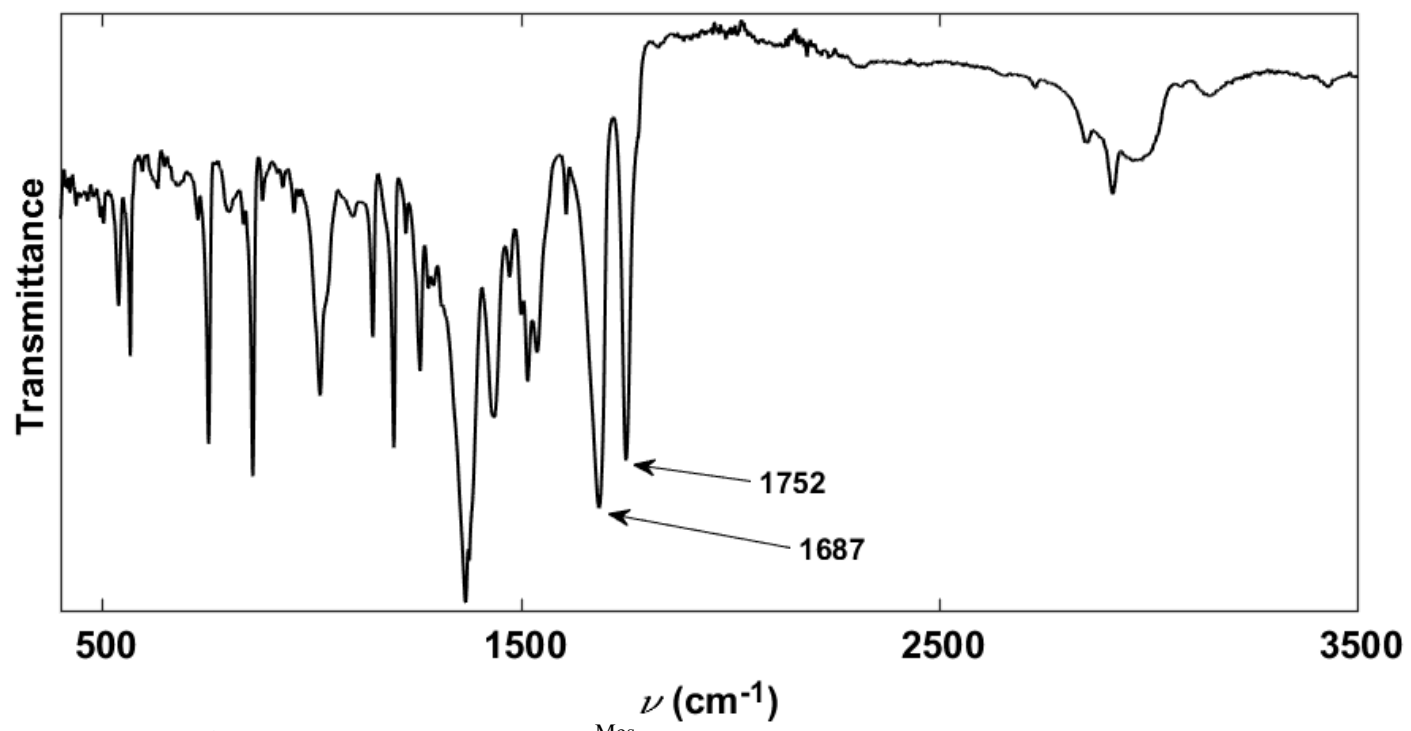

Figure S2. FTIR spectrum of $\left[\left(\mathrm{L}^{\mathrm{Mes}}\right) \mathrm{Fe}(\mathrm{NO})_{2}\right]$. The NO stretches are labelled. 


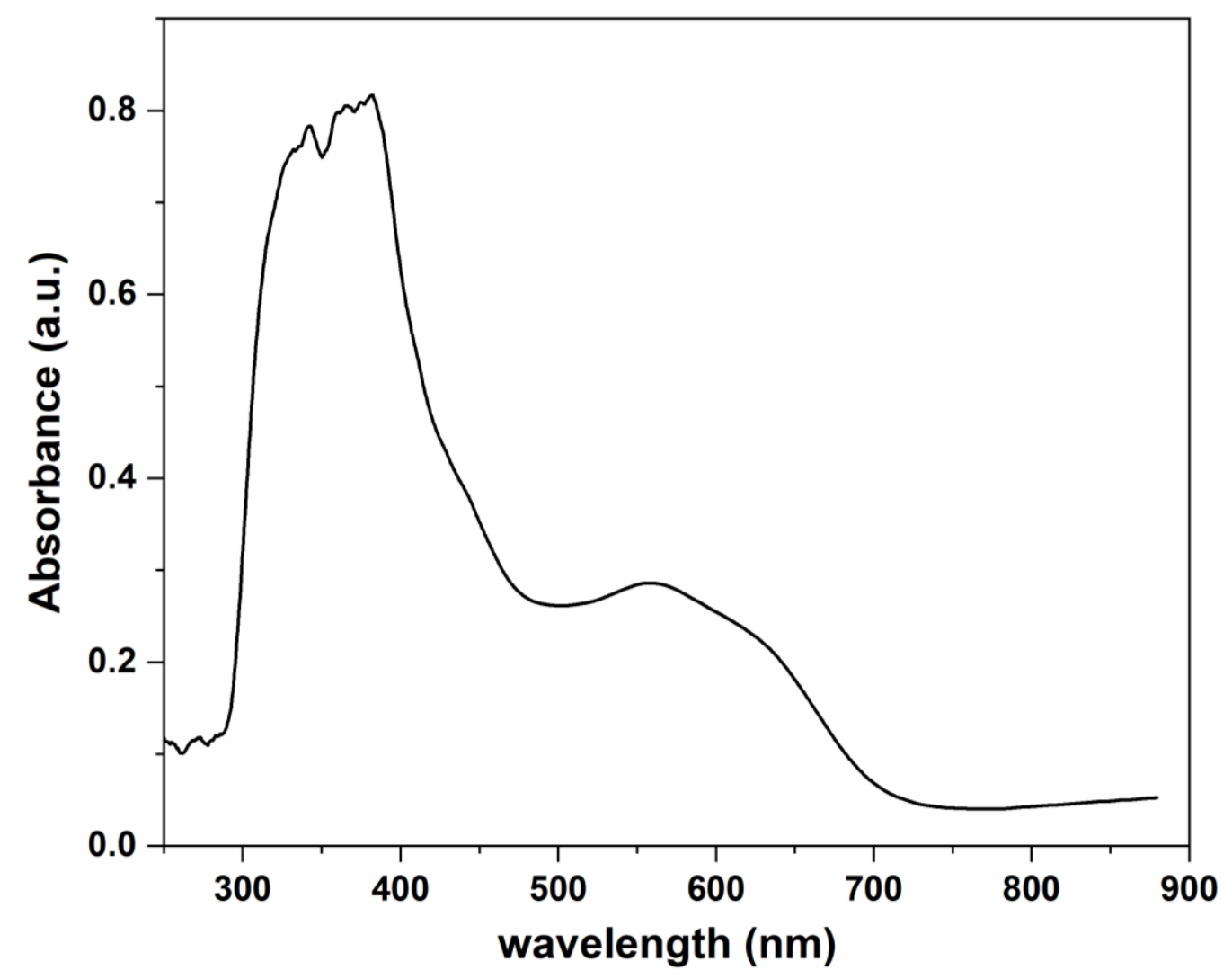

Figure S3. UV-vis spectrum of $\left[\left(\mathrm{L}^{\mathrm{Mes}}\right) \mathrm{Fe}(\mathrm{NO})_{2}\right]$ in toluene $(0.1 \mathrm{mM})$ at room temperature.

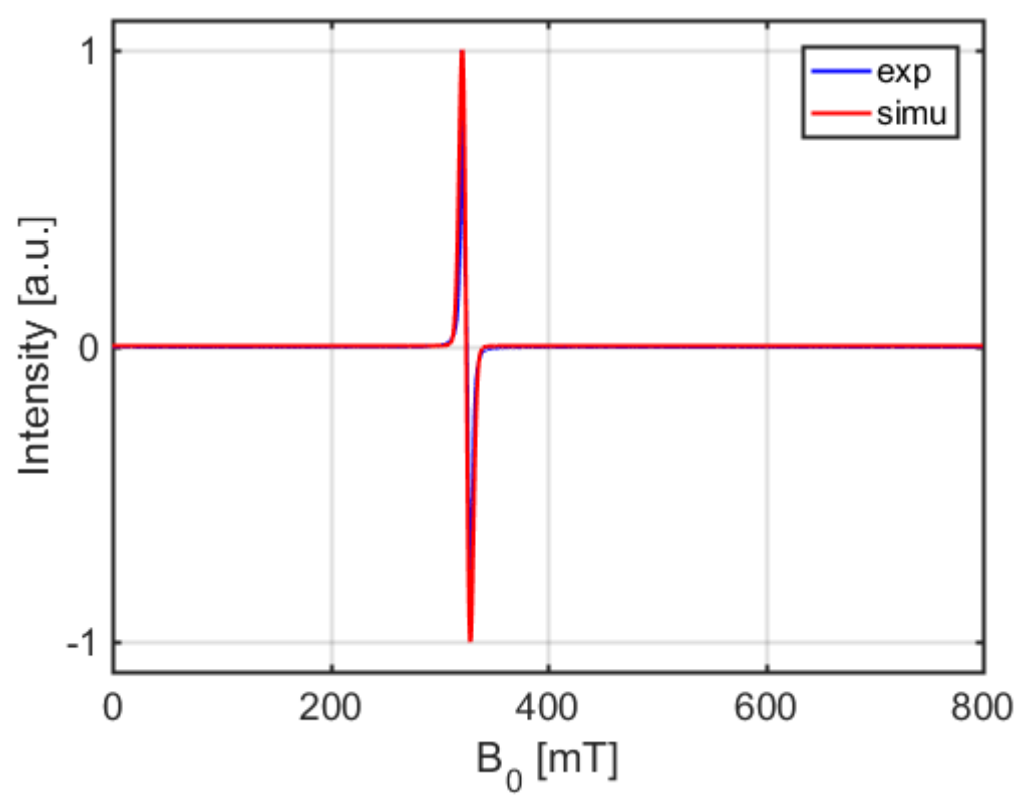

Figure S4. X-Band CW-EPR spectrum (blue line) recorded on a polycrystalline solid sample of $\left[\left(\mathrm{L}^{\mathrm{Mes}}\right) \mathrm{Fe}(\mathrm{NO})_{2}\right]$ at 298 $\mathrm{K}$. The simulation (red line) was obtained using EasySpin with the standard pepper function and the parameters $S=1 / 2$, $g_{\text {iso }}=2.06, D=-1.7 \times 10^{-4} \mathrm{~cm}^{-1},|E||D|=1 \times 10^{-3} \mathrm{~cm}^{-1}$, Gaussian linewidth $=0.01 \mathrm{mT}$, Lorentzian linewidth $=0.5 \mathrm{mT}$. 


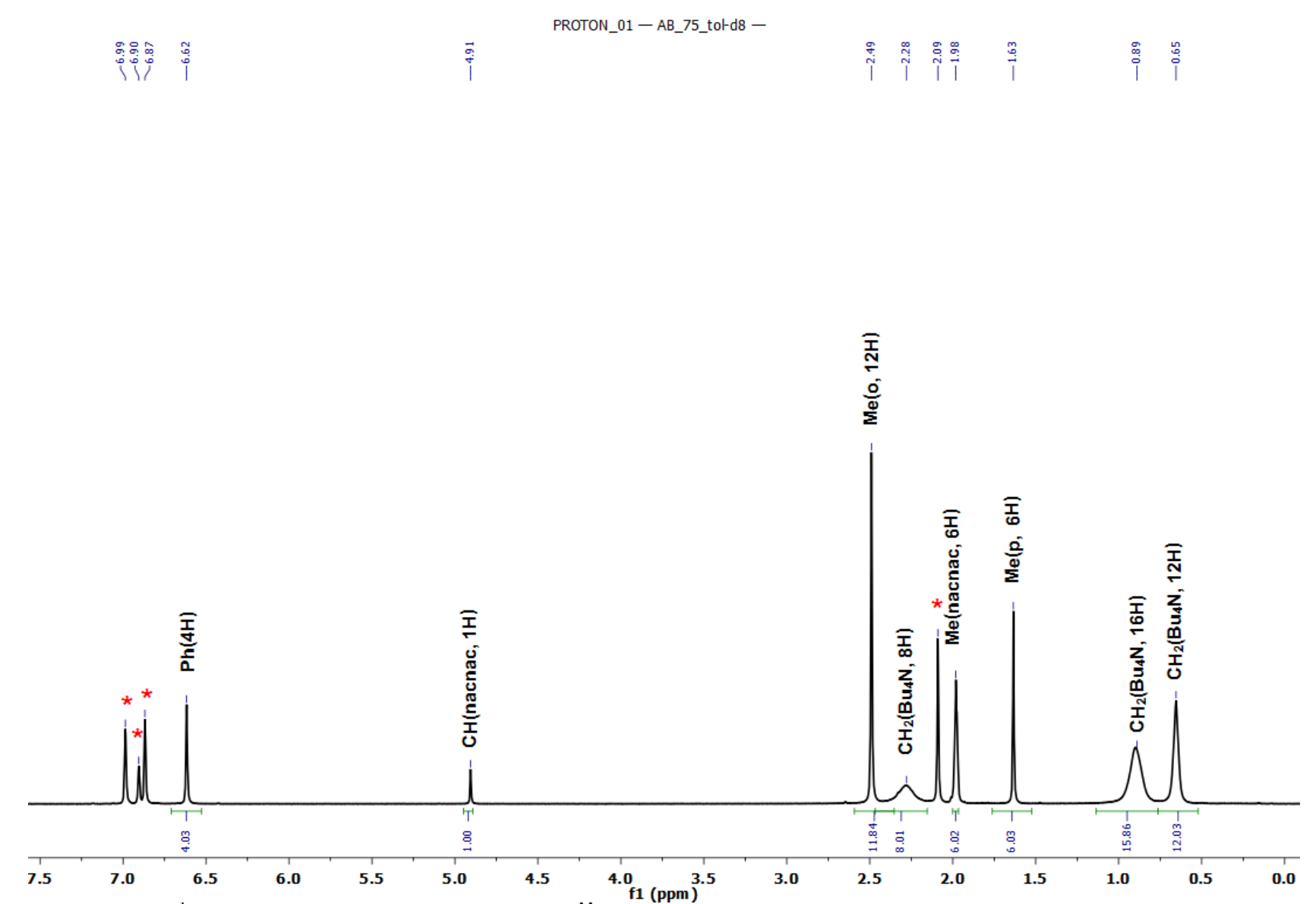

Figure S5. ${ }^{1} \mathrm{H}$ NMR spectrum of $\left[\mathrm{Bu}_{4} \mathrm{~N}\right]\left[\left(\mathrm{L}^{\mathrm{Mes}}\right) \mathrm{Fe}(\mathrm{NO})_{2}\right](\mathbf{1 a})$ in toluene- $\mathrm{D}_{8}$ at $298 \mathrm{~K}$. The red asterisks correspond to residual solvent peaks. 

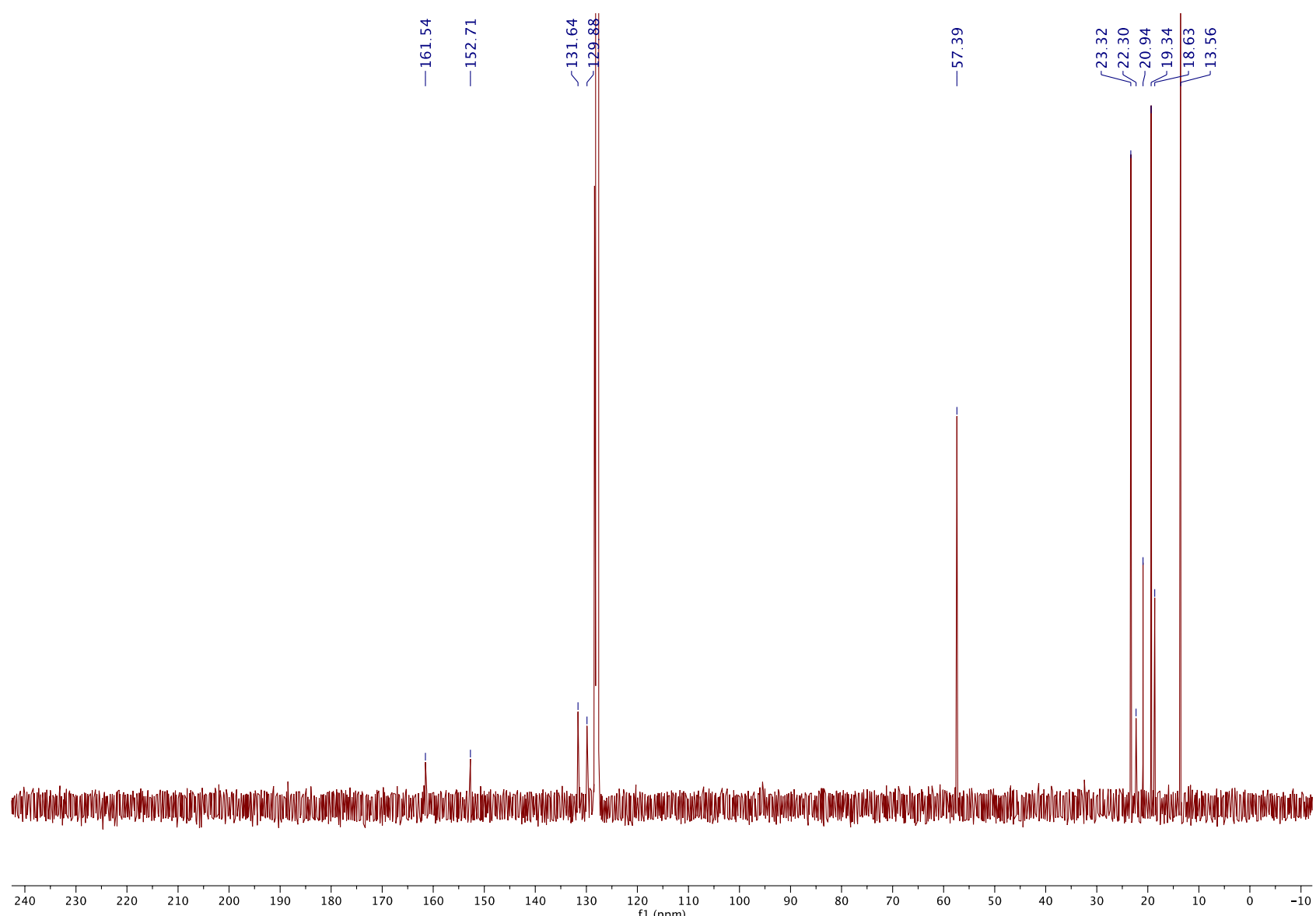

Figure S6. ${ }^{13} \mathrm{C}$ NMR spectrum of $\left[\mathrm{Bu}_{4} \mathrm{~N}\right]\left[\left(\mathrm{L}^{\mathrm{Mes}}\right) \mathrm{Fe}(\mathrm{NO})_{2}\right](\mathbf{1 a})$ in benzene- $\mathrm{D}_{6}$ at $298 \mathrm{~K}$. 


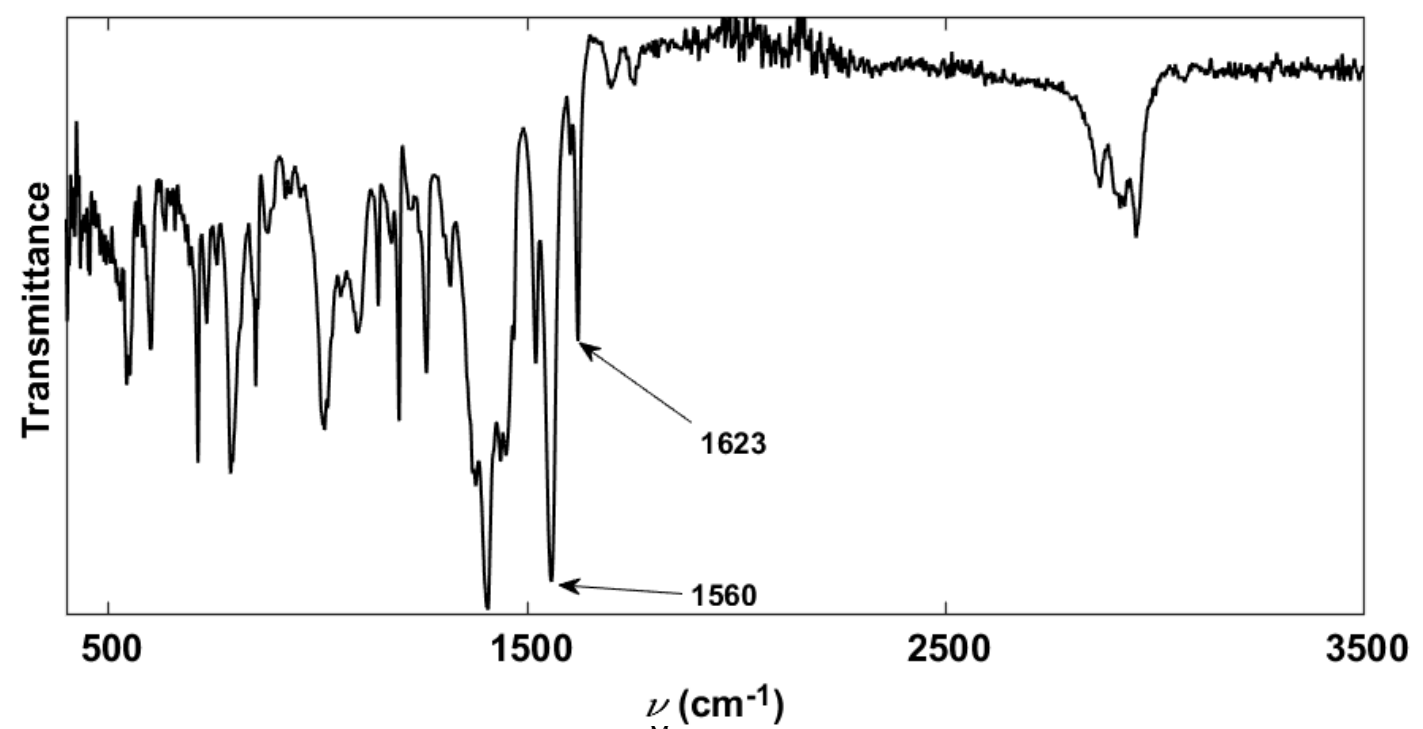

Figure S7. FTIR spectrum of $\left[\mathrm{Bu}_{4} \mathrm{~N}\right]\left[\left(\mathrm{L}^{\mathrm{Mes}}\right) \mathrm{Fe}(\mathrm{NO})_{2}\right](\mathbf{1 a})$. The NO stretches are labelled. 


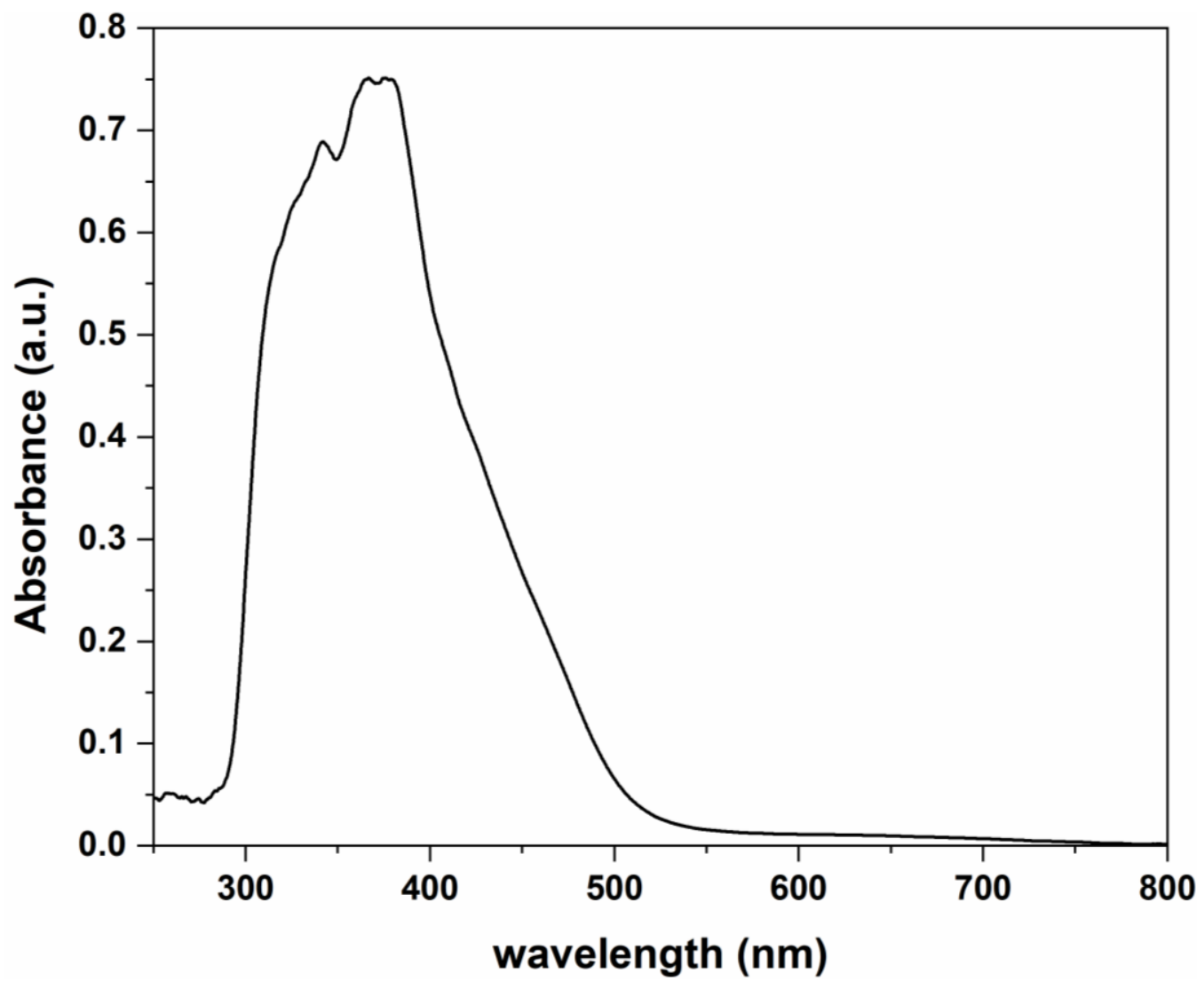

Figure S8. UV-vis spectrum of $\left[\mathrm{Bu}_{4} \mathrm{~N}\right]\left[\left(\mathrm{L}^{\mathrm{Mes}}\right) \mathrm{Fe}(\mathrm{NO})_{2}\right](\mathbf{1 a})$ in toluene $(0.1 \mathrm{mM})$ at room temperature. 


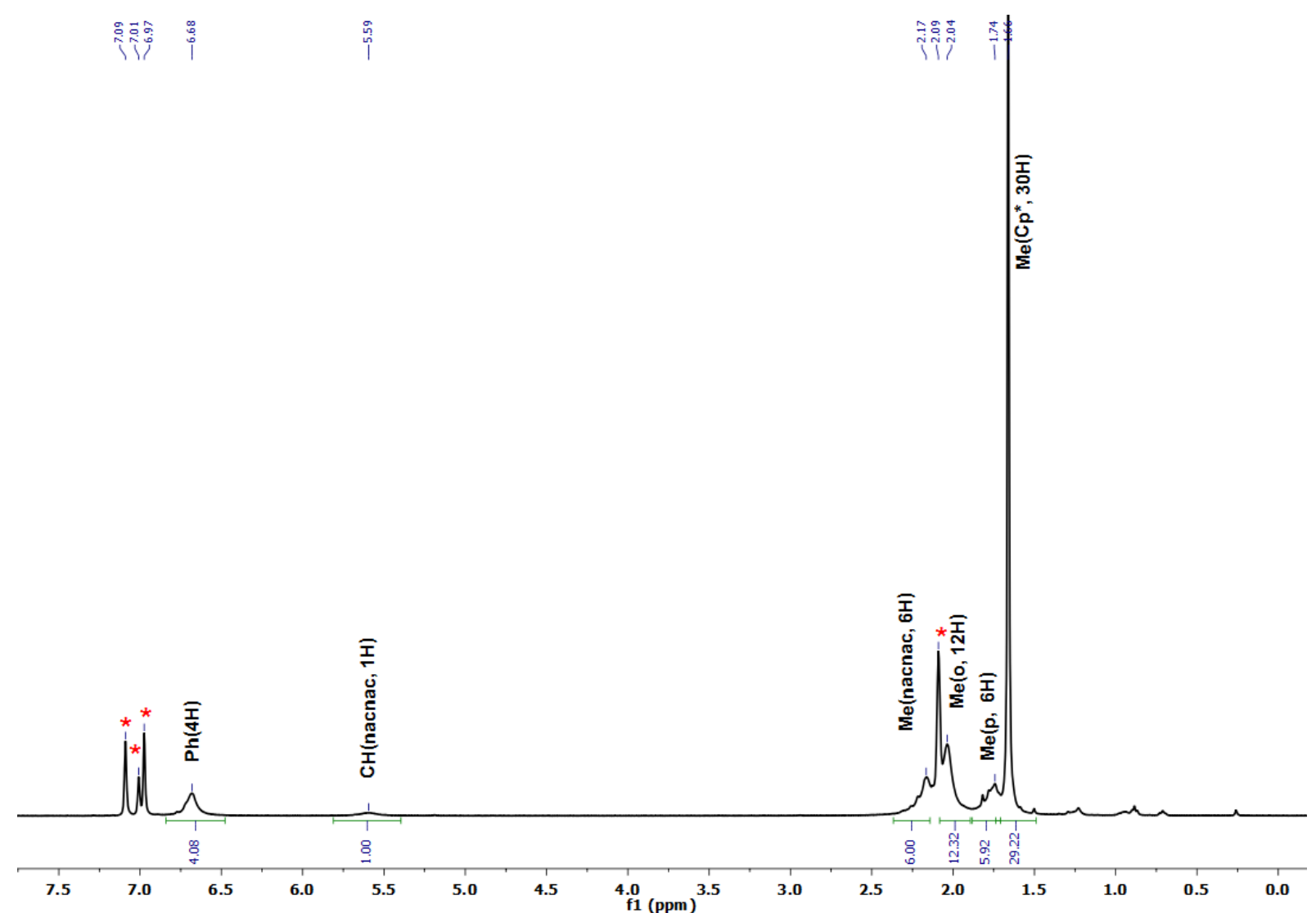

Figure S9. ${ }^{1} \mathrm{H}$ NMR spectrum of $\left[\left(\mathrm{Cp}^{*}\right)_{2} \mathrm{Y}(\mathrm{ON})_{2} \mathrm{Fe}\left(\mathrm{L}^{\mathrm{Mes}}\right)\right]\left(\mathbf{2}_{\mathrm{Y}}\right)$ in toluene- $\mathrm{D}_{8}$ at $298 \mathrm{~K}$. The red asterisks correspond to residual solvent peaks.
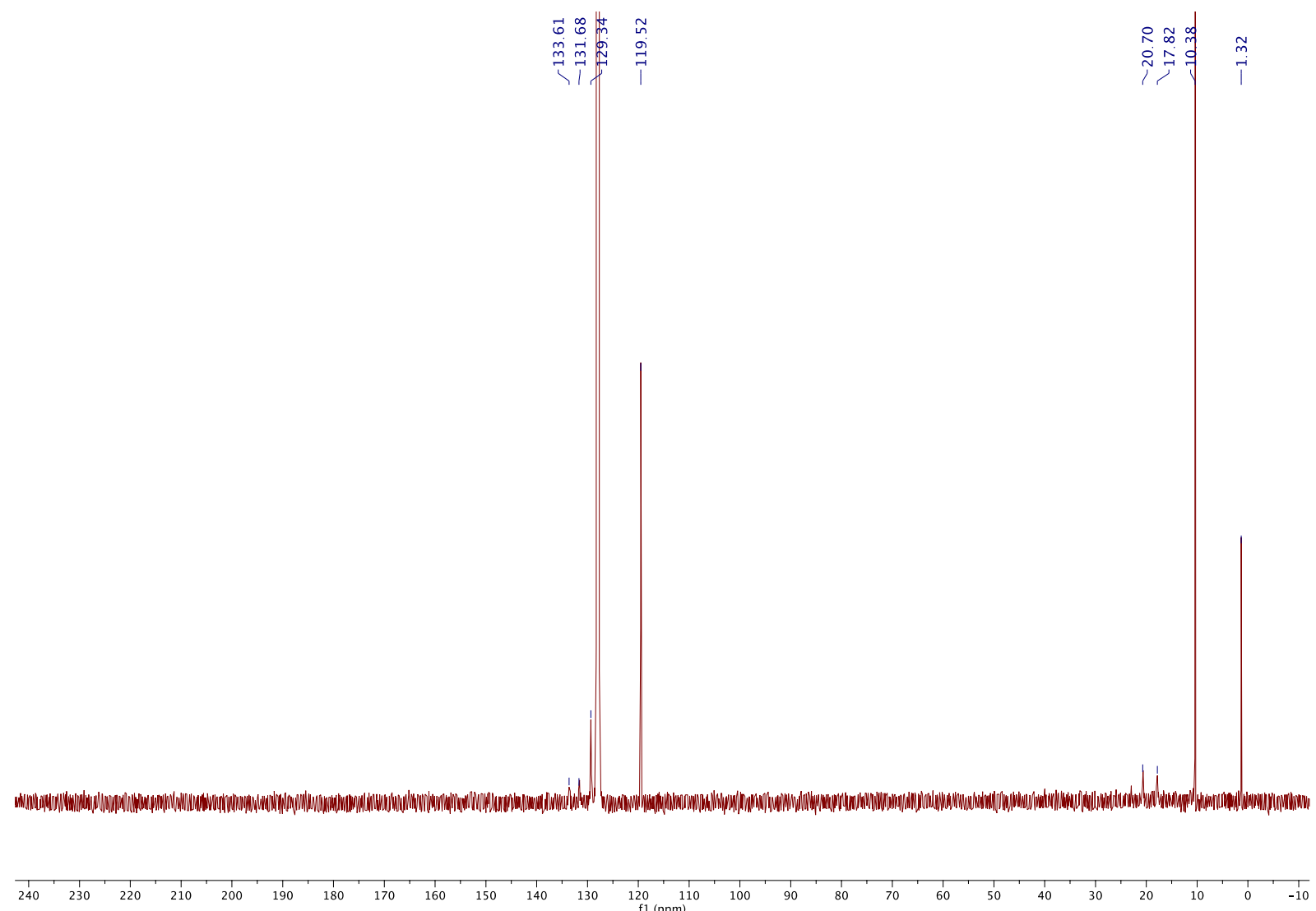

Figure S10. ${ }^{13} \mathrm{C}$ NMR spectrum of $\left[\left(\mathrm{Cp}^{*}\right)_{2} \mathrm{Y}(\mathrm{ON})_{2} \mathrm{Fe}\left(\mathrm{L}^{\mathrm{Mes}}\right)\right]\left(\mathbf{2}_{\mathrm{Y}}\right)$ in benzene- $\mathrm{D}_{6}$ at $298 \mathrm{~K}$. 


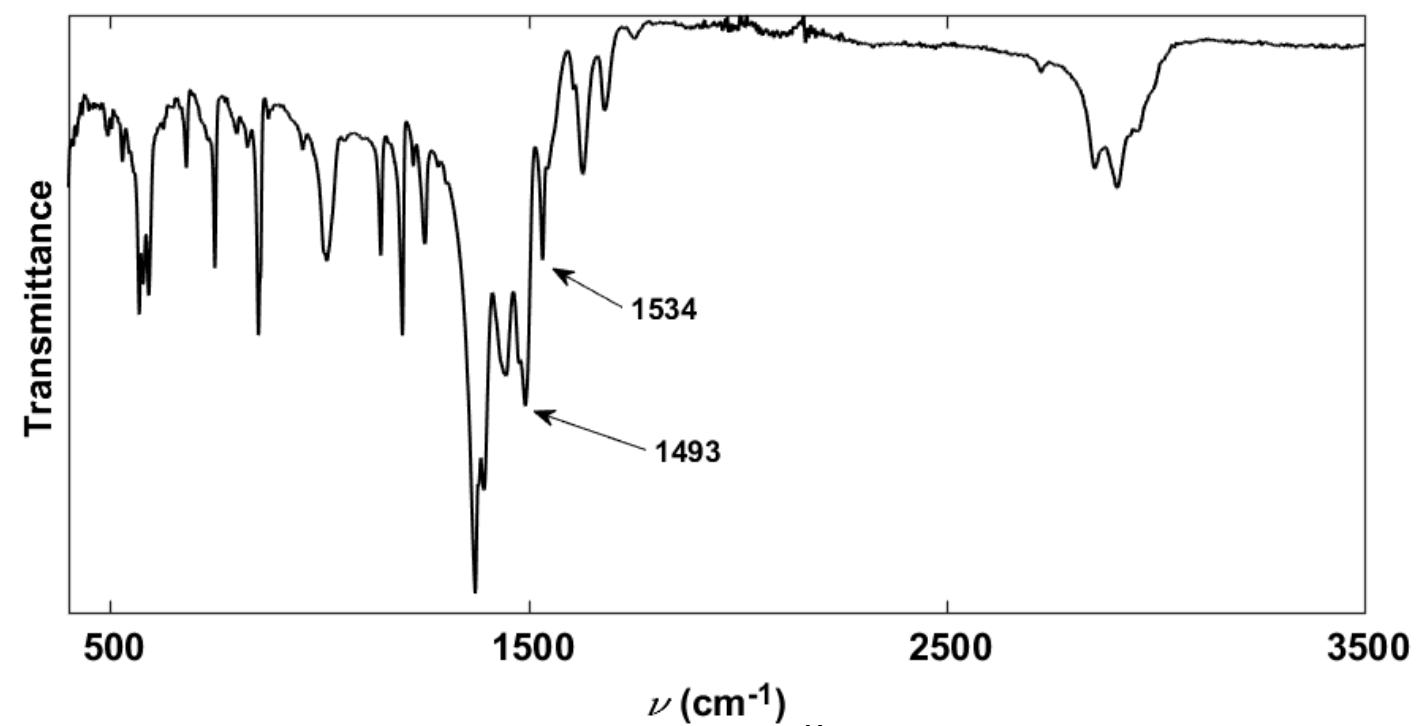

Figure S11. FTIR spectrum of $\left[\left(\mathrm{Cp}^{*}\right)_{2} \mathrm{Y}(\mathrm{ON})_{2} \mathrm{Fe}\left(\mathrm{L}^{\mathrm{Mes}}\right)\right]\left(\mathbf{2}_{\mathrm{Y}}\right)$. The NO stretches are labelled. 


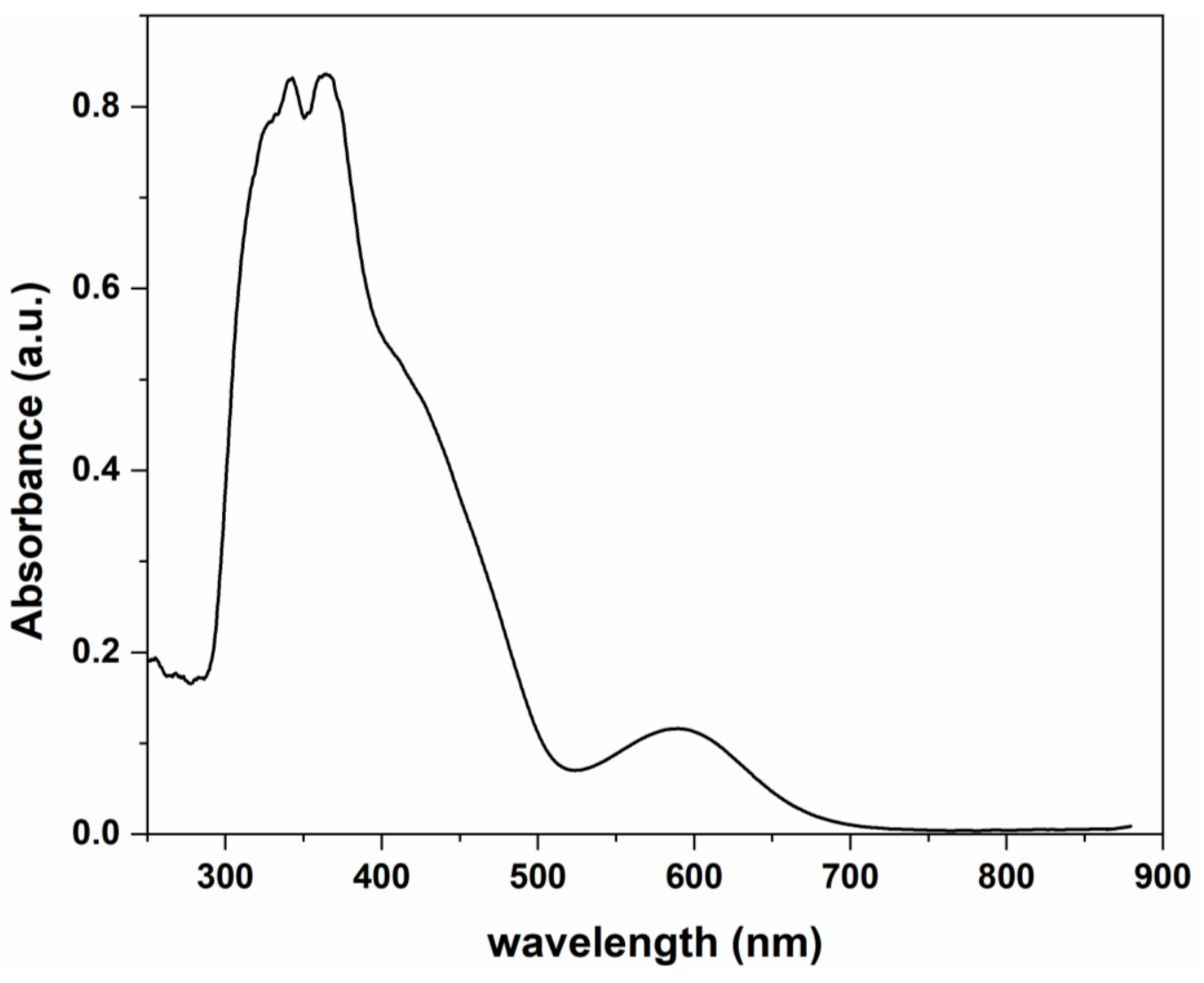

Figure S12. UV-vis spectrum of $\left[\left(\mathrm{Cp}^{*}\right)_{2} \mathrm{Y}(\mathrm{ON})_{2} \mathrm{Fe}\left(\mathrm{L}^{\mathrm{Mes}}\right)\right]\left(\mathbf{2}_{\mathrm{Y}}\right)$ in toluene $(0.1 \mathrm{mM})$ at room temperature. 


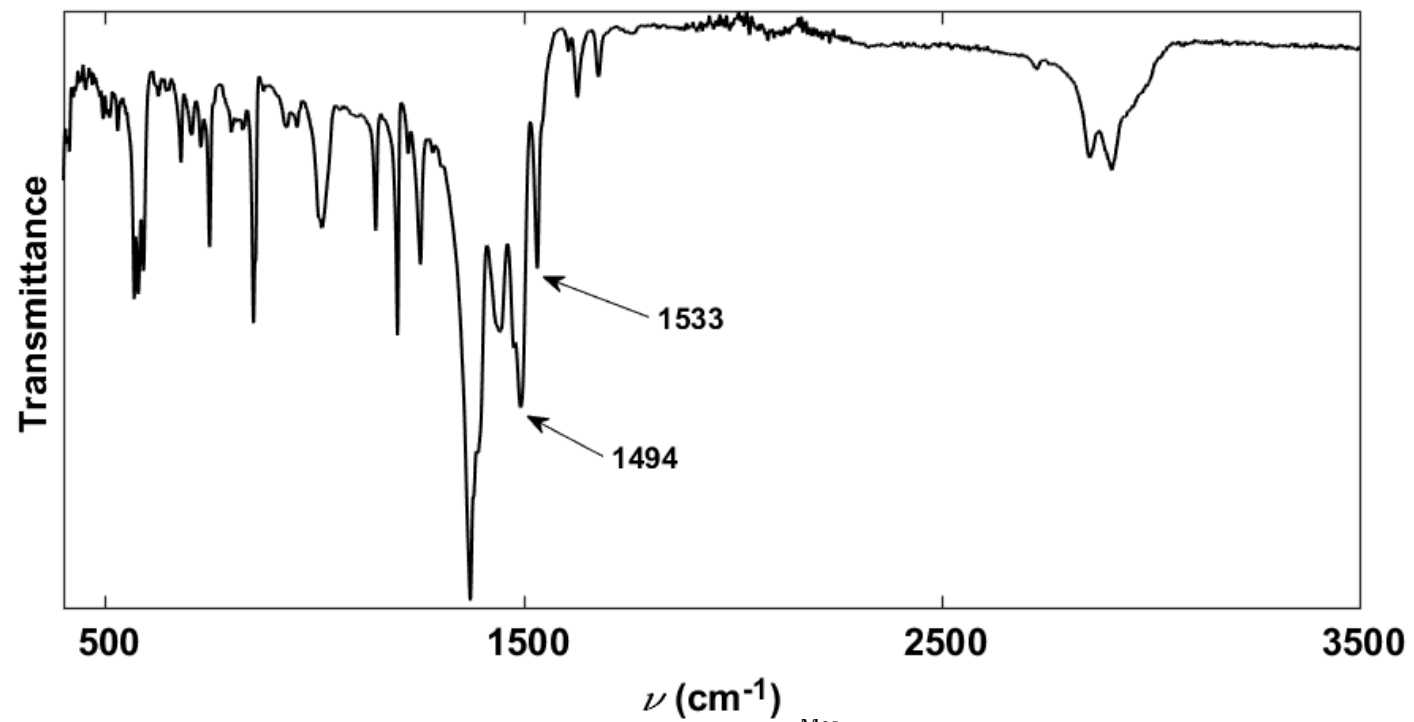

Figure S13. FTIR spectrum of $\left[\left(\mathrm{Cp}^{*}\right)_{2} \mathrm{Gd}(\mathrm{ON})_{2} \mathrm{Fe}\left(\mathrm{L}^{\mathrm{Mes}}\right)\right]\left(\mathbf{2}_{\mathbf{G d}}\right)$. The NO stretches are labelled. 


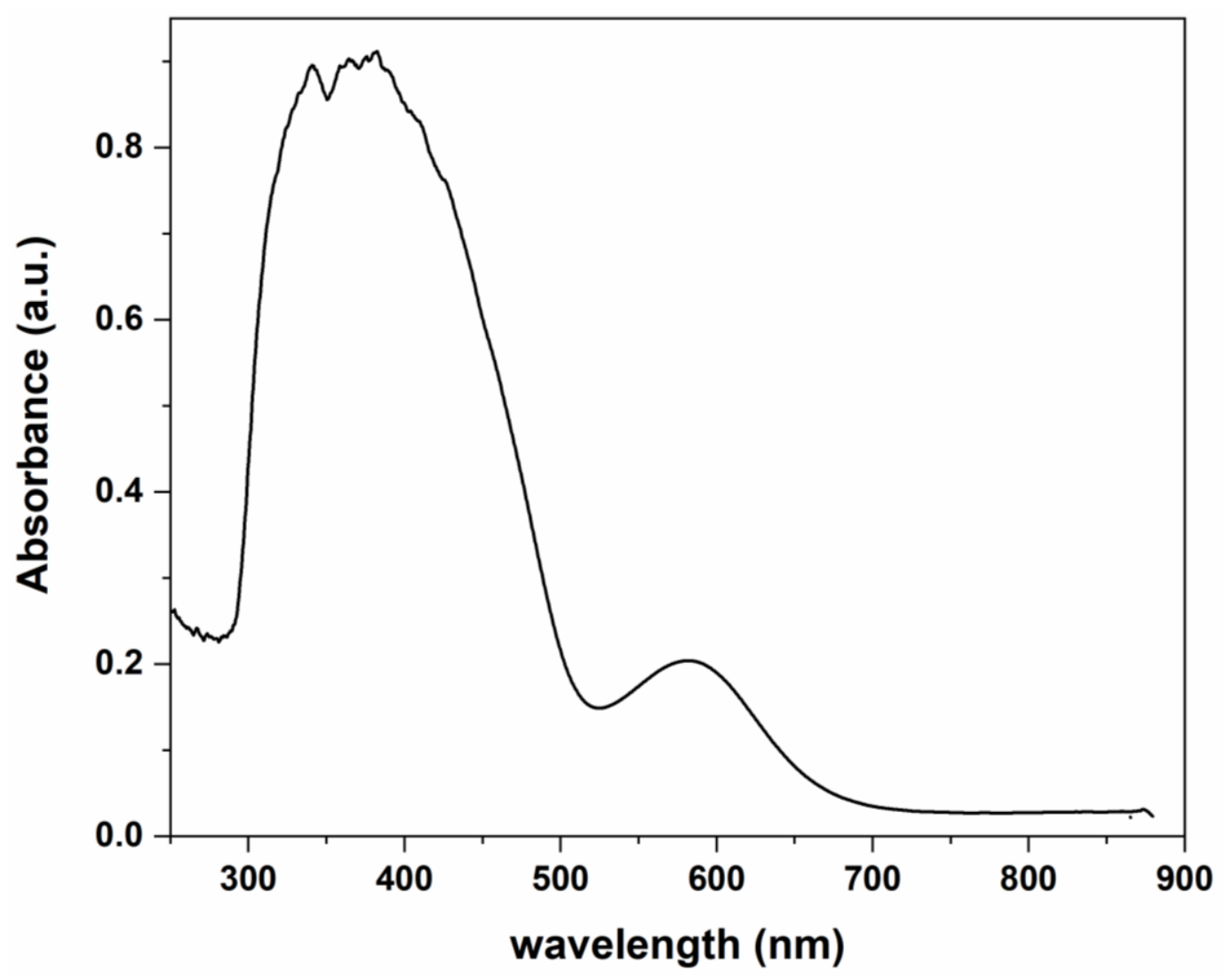

Figure S14. UV-vis spectrum of $\left[\left(\mathrm{Cp}^{*}\right)_{2} \mathrm{Gd}(\mathrm{ON})_{2} \mathrm{Fe}\left(\mathrm{L}^{\mathrm{Mes}}\right)\right]\left(\mathbf{2}_{\mathrm{Gd}}\right)$ in toluene $(0.1 \mathrm{mM})$ at room temperature.

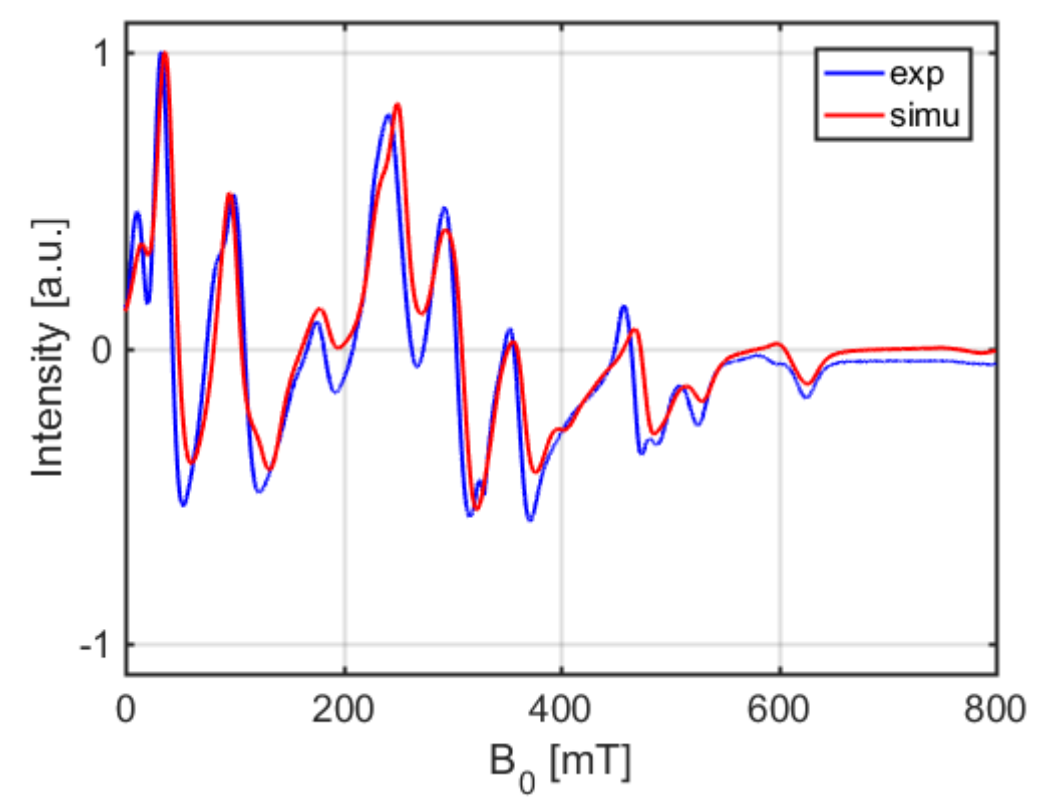

Figure S15. X-Band CW-EPR spectrum (blue line) recorded on a polycrystalline solid sample of $\left[\left(\mathrm{Cp}^{*}\right)_{2} \mathrm{Gd}(\mathrm{ON})_{2} \mathrm{Fe}\left(\mathrm{L}^{\mathrm{Mes}}\right)\right]\left(\mathbf{2}_{\mathbf{G d}}\right)$ at $298 \mathrm{~K}$. The simulation (red line) was obtained using EasySpin with the standard pepper function and the parameters $S=7 / 2, g_{\text {iso }}=1.99, D=-6.9 \times 10^{-2} \mathrm{~cm}^{-1},|E||D|=0.33$, Gaussian linewidth $=8 \mathrm{mT}$, Lorentzian linewidth $=8 \mathrm{mT}$. 


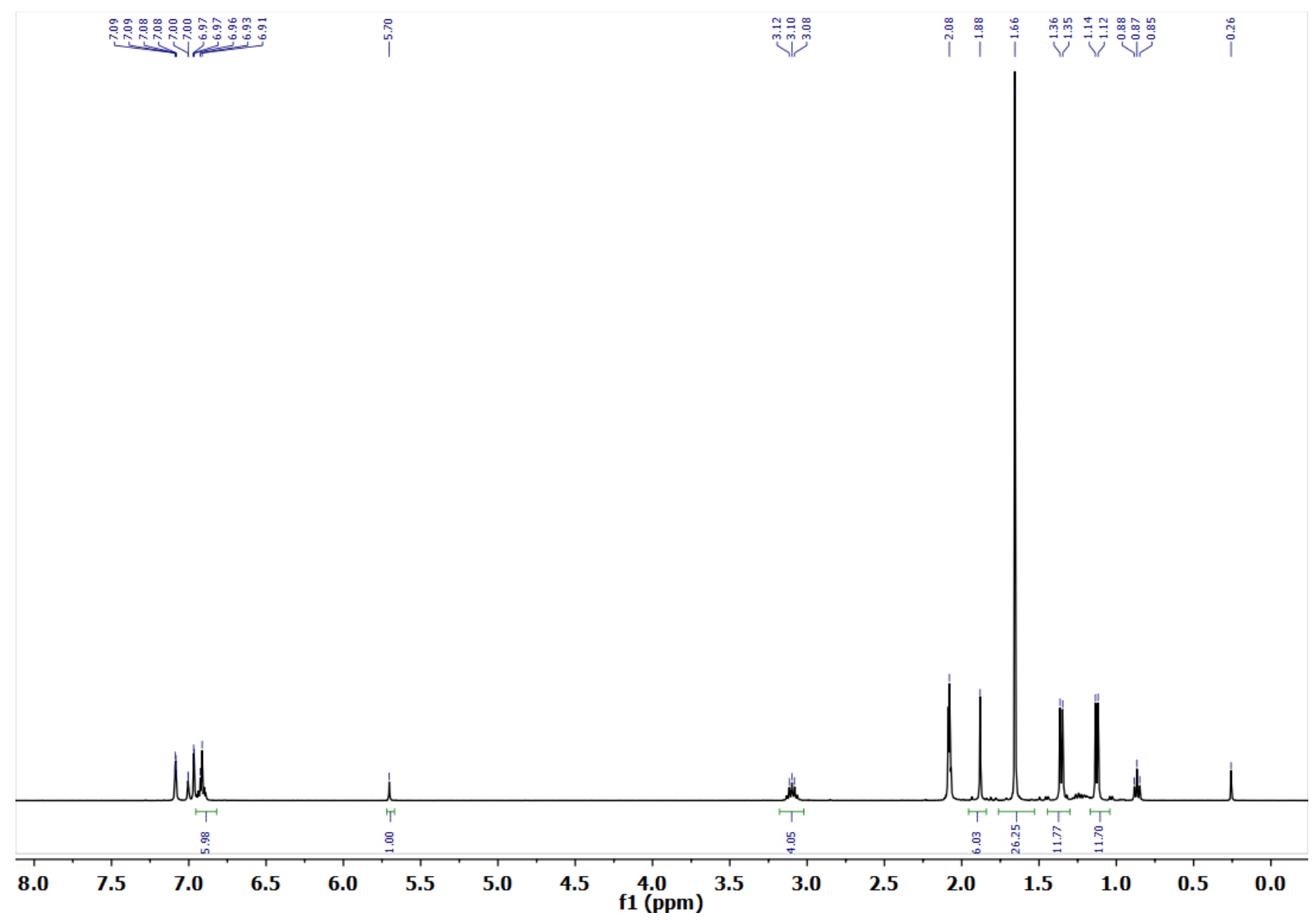

Figure S16. ${ }^{1} \mathrm{H}$ NMR spectrum of $\left[\left(\mathrm{Cp}^{*}\right)_{2} \mathrm{Y}(\mathrm{ON})_{2} \mathrm{Fe}\left(\mathrm{L}^{\text {Dipp }}\right)\right]\left(\mathbf{3}_{\mathrm{Y}}\right)$ in toluene- $\mathrm{D}_{8}$ at $298 \mathrm{~K}$. 


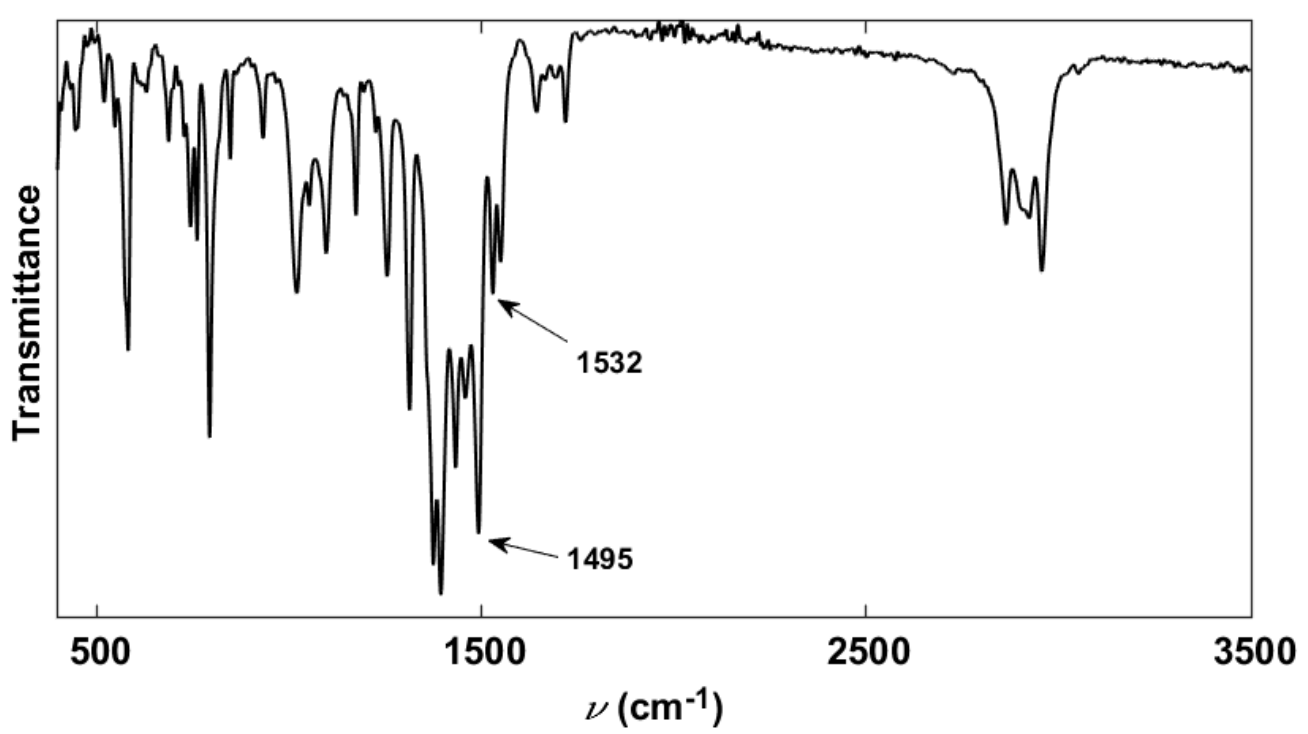

Figure S17. FTIR spectrum of $\left[\left(\mathrm{Cp}^{*}\right)_{2} \mathrm{Y}(\mathrm{ON})_{2} \mathrm{Fe}\left(\mathrm{L}^{\text {Dipp }}\right)\right]\left(\mathbf{3}_{\mathrm{Y}}\right)$. The NO stretches are labelled. 


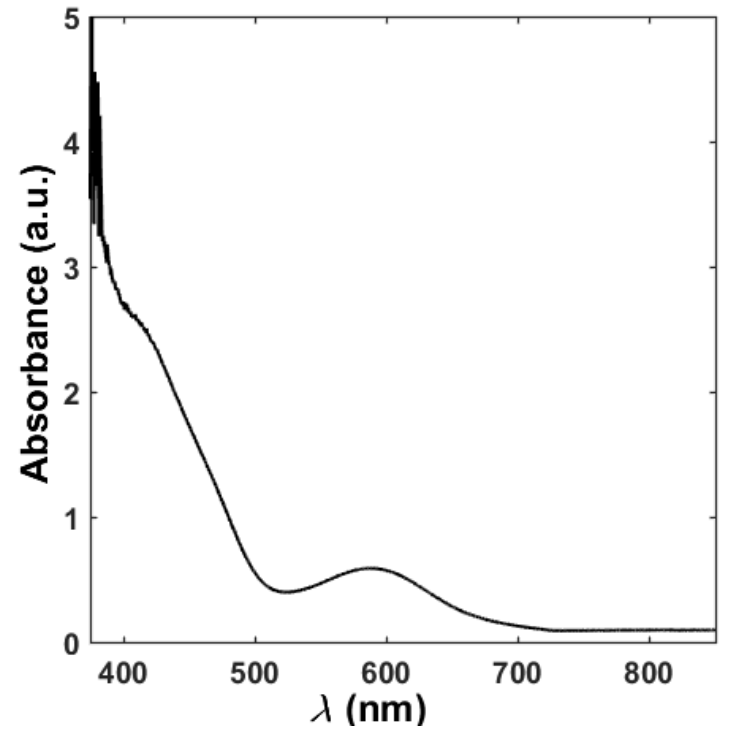

Figure S18. UV-vis spectrum of $\left[\left(\mathrm{Cp}^{*}\right)_{2} \mathrm{Y}(\mathrm{ON})_{2} \mathrm{Fe}\left(\mathrm{L}^{\text {Dipp }}\right)\right]\left(\mathbf{3}_{\mathrm{Y}}\right)$ in toluene $(0.1 \mathrm{mM})$ at room temperature. 


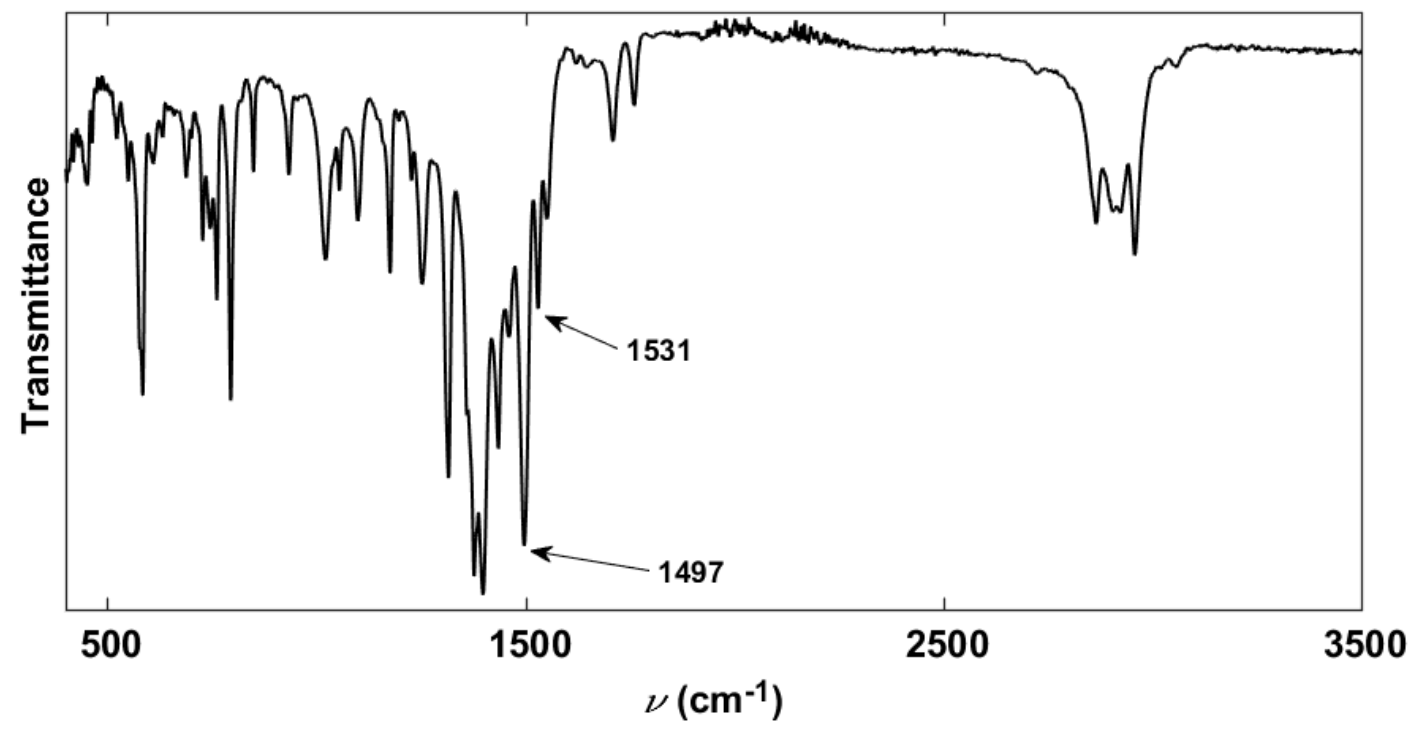

Figure S19. FTIR spectrum of $\left[\left(\mathrm{Cp}^{*}\right)_{2} \mathrm{Gd}(\mathrm{ON})_{2} \mathrm{Fe}\left(\mathrm{L}^{\text {Dipp }}\right)\right]\left(\mathbf{3}_{\mathbf{G d}}\right)$. The NO stretches are labelled. 


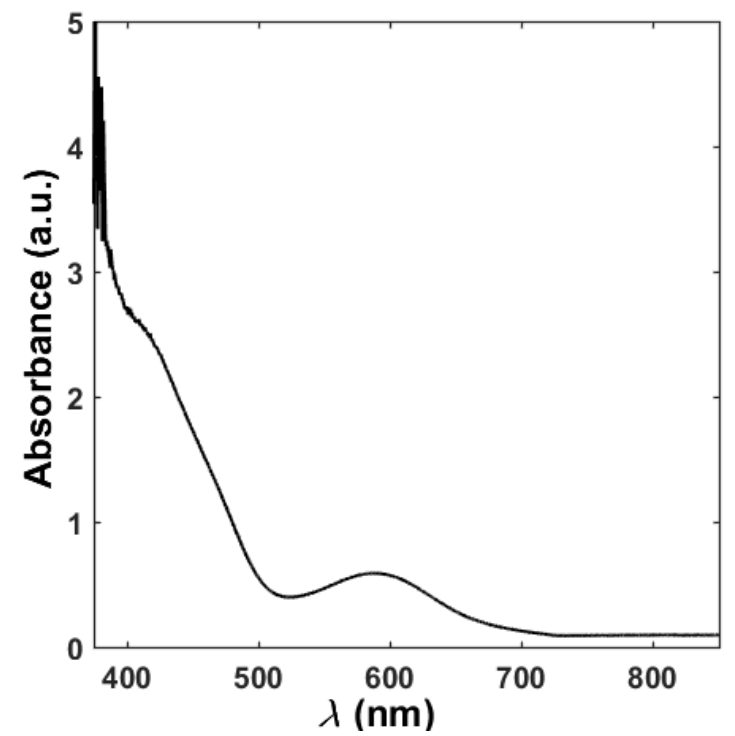

Figure S20. UV-vis spectrum of $\left[\left(\mathrm{Cp}^{*}\right)_{2} \mathrm{Gd}(\mathrm{ON})_{2} \mathrm{Fe}\left(\mathrm{L}^{\mathrm{Dipp}}\right)\right]\left(\mathbf{3}_{\mathrm{Gd}}\right)$ in toluene $(0.1 \mathrm{mM})$ at room temperature.

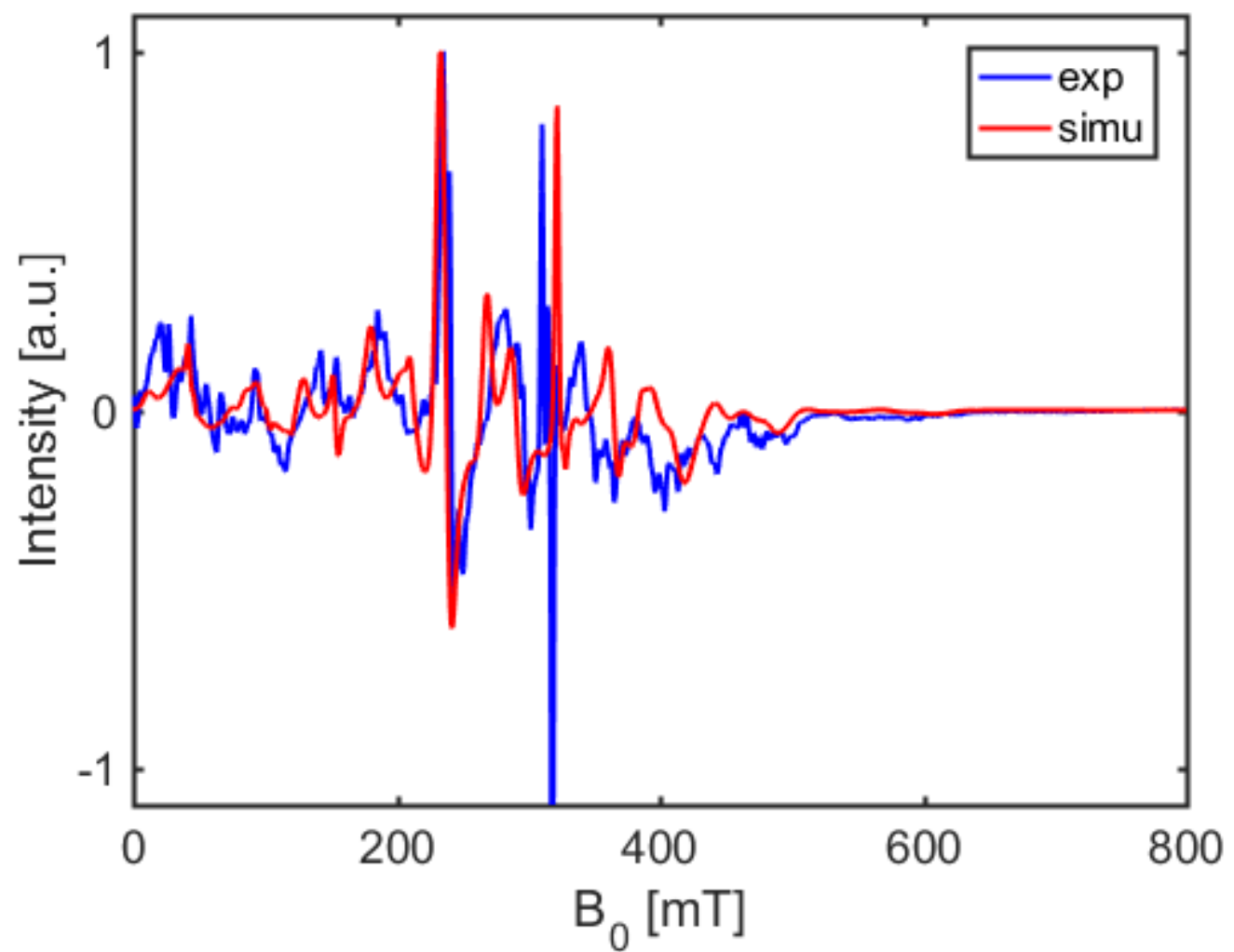

Figure S21. X-Band CW-EPR spectrum (blue line) recorded on a frozen toluene solution of $\left[\left(\mathrm{Cp}^{*}\right)_{2} \mathrm{Gd}(\mathrm{ON})_{2} \mathrm{Fe}\left(\mathrm{L}^{\text {Dipp }}\right)\right]\left(\mathbf{3}_{\mathrm{Gd}}\right)$ at $95 \mathrm{~K}$. The simulation (red line) was obtained using EasySpin with the standard pepper function and the parameters $S=7 / 2$, rhombic $g$-factors $g_{x}=1.980, g_{y}=1.999, g_{z}=2.00, D=-6.64 \times 10^{-2} \mathrm{~cm}^{-1}$, $|E||D|=4.85 \times 10^{-2}$, Gaussian linewidth $=8 \mathrm{mT}$, Lorentzian linewidth $=8 \mathrm{mT}$. 


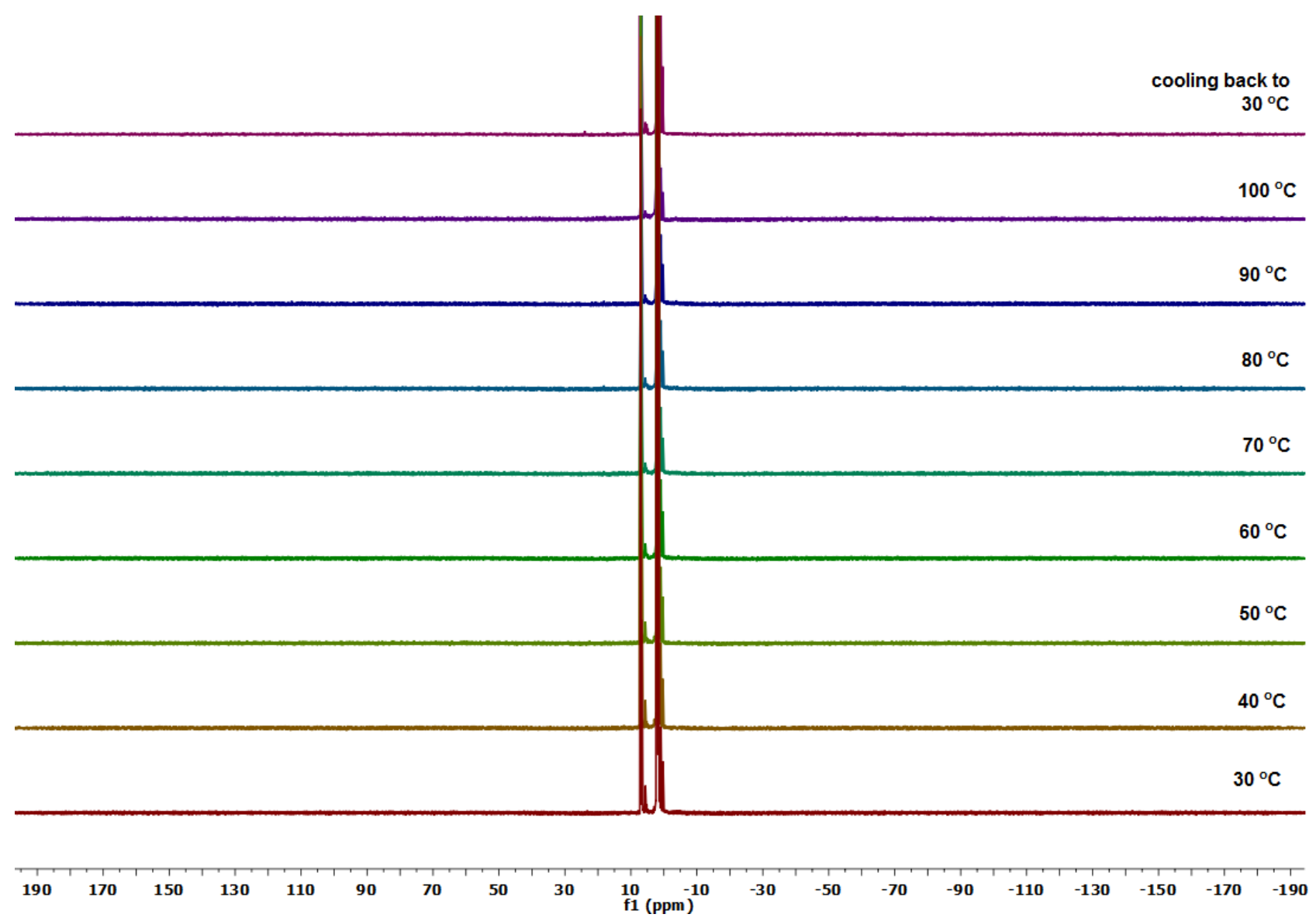

Figure S22. Variable-temperature ${ }^{1} \mathrm{H}$ NMR spectra of $\mathbf{2}_{\mathrm{Y}}$ in toluene- $\mathrm{D}_{8}$ after heating at the temperatures indicated. 


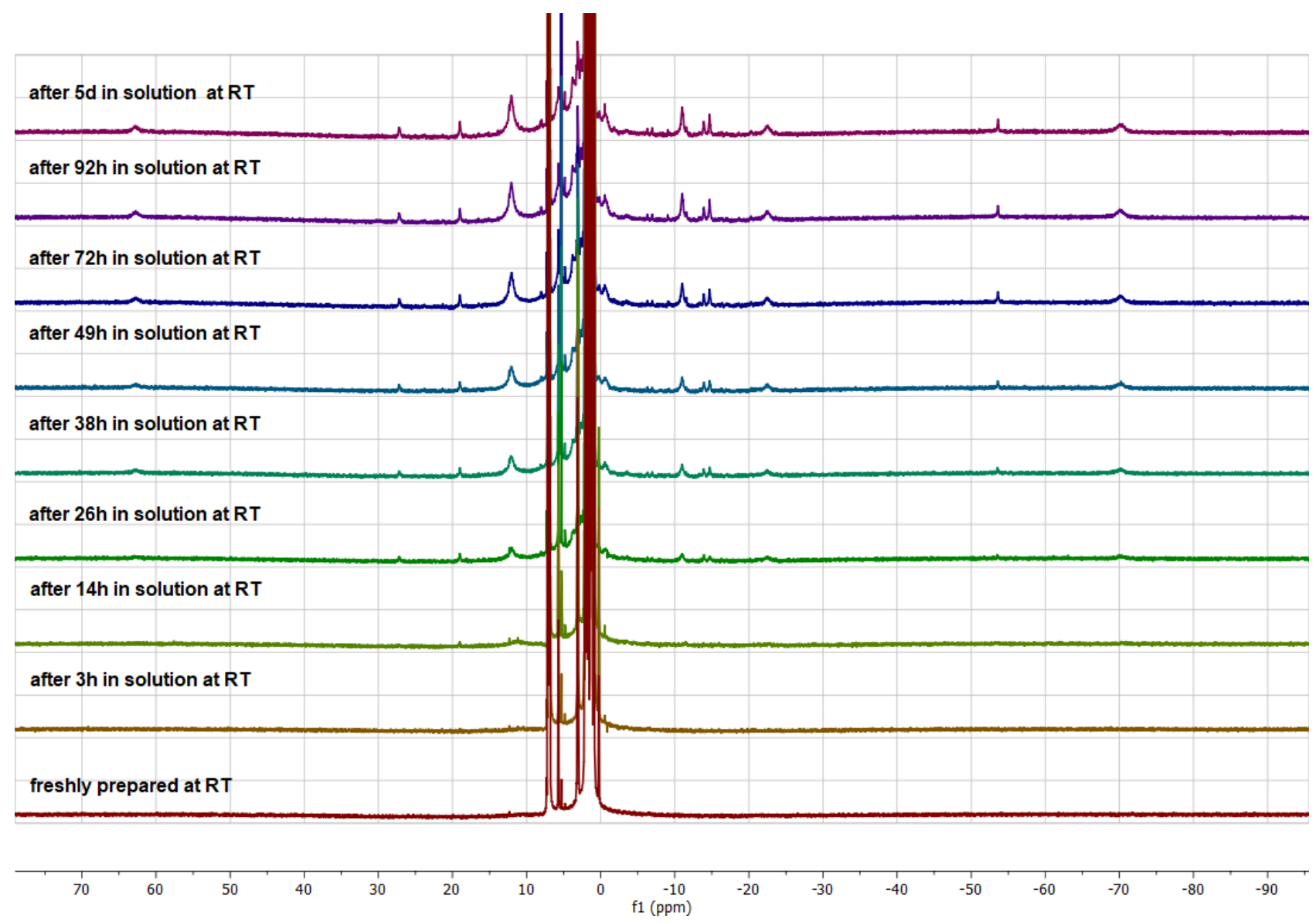

Figure S23. Variable-time ${ }^{1} \mathrm{H}$ NMR spectra of $\mathbf{3}_{\mathbf{Y}}$ in toluene- $\mathrm{D}_{8}$ recorded at $298 \mathrm{~K}$ and various intervals over a five-day period. 


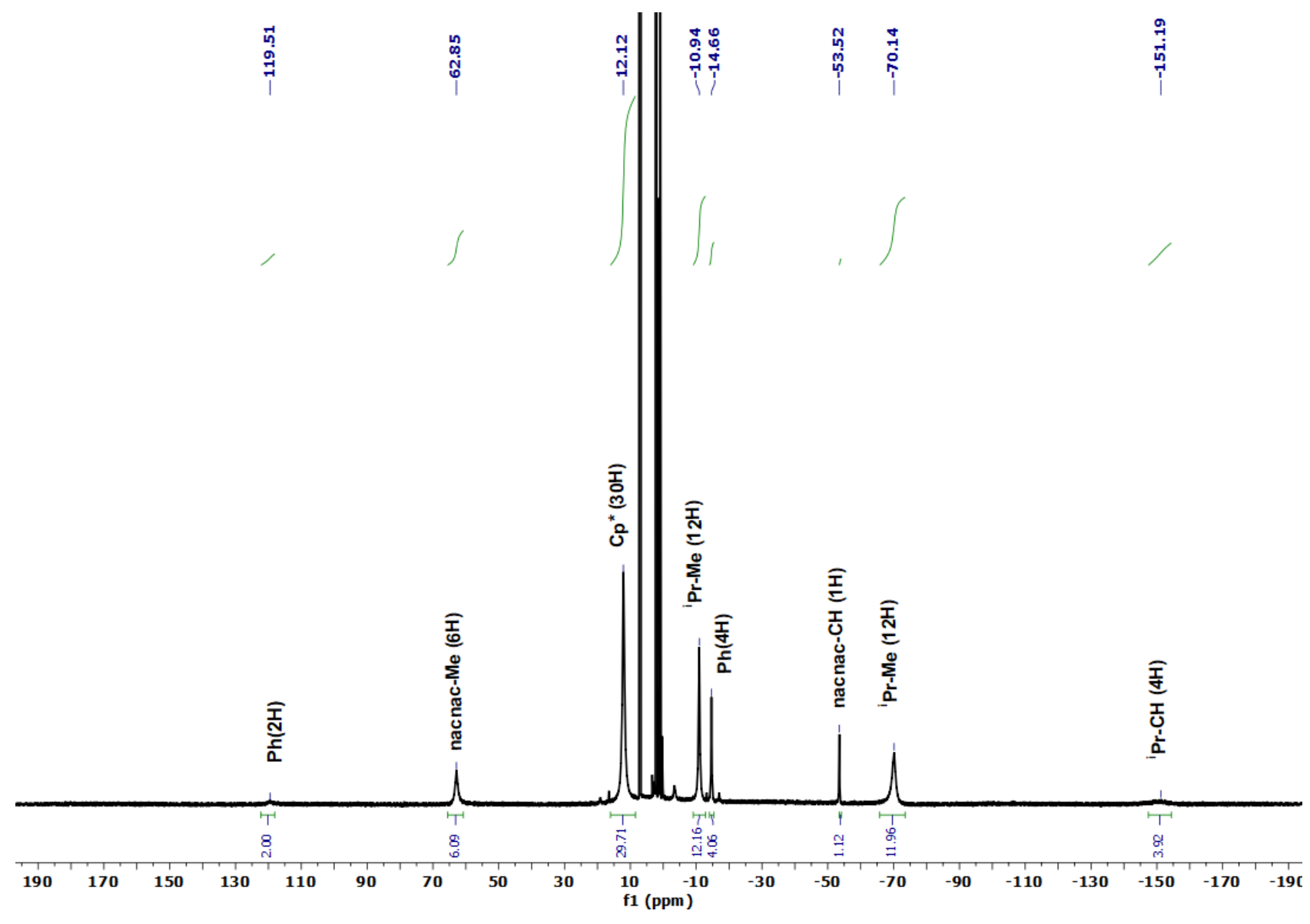

Figure S24. ${ }^{1} \mathrm{H}$ NMR spectrum of $\left[\left(\mathrm{Cp}^{*}\right)_{2} \mathrm{YOFe}\left(\mathrm{L}^{\mathrm{Dipp}}\right)\right]\left(\mathbf{4}_{\mathbf{Y}}\right)$ in toluene- $\mathrm{D}_{8}$ at $298 \mathrm{~K}$. 


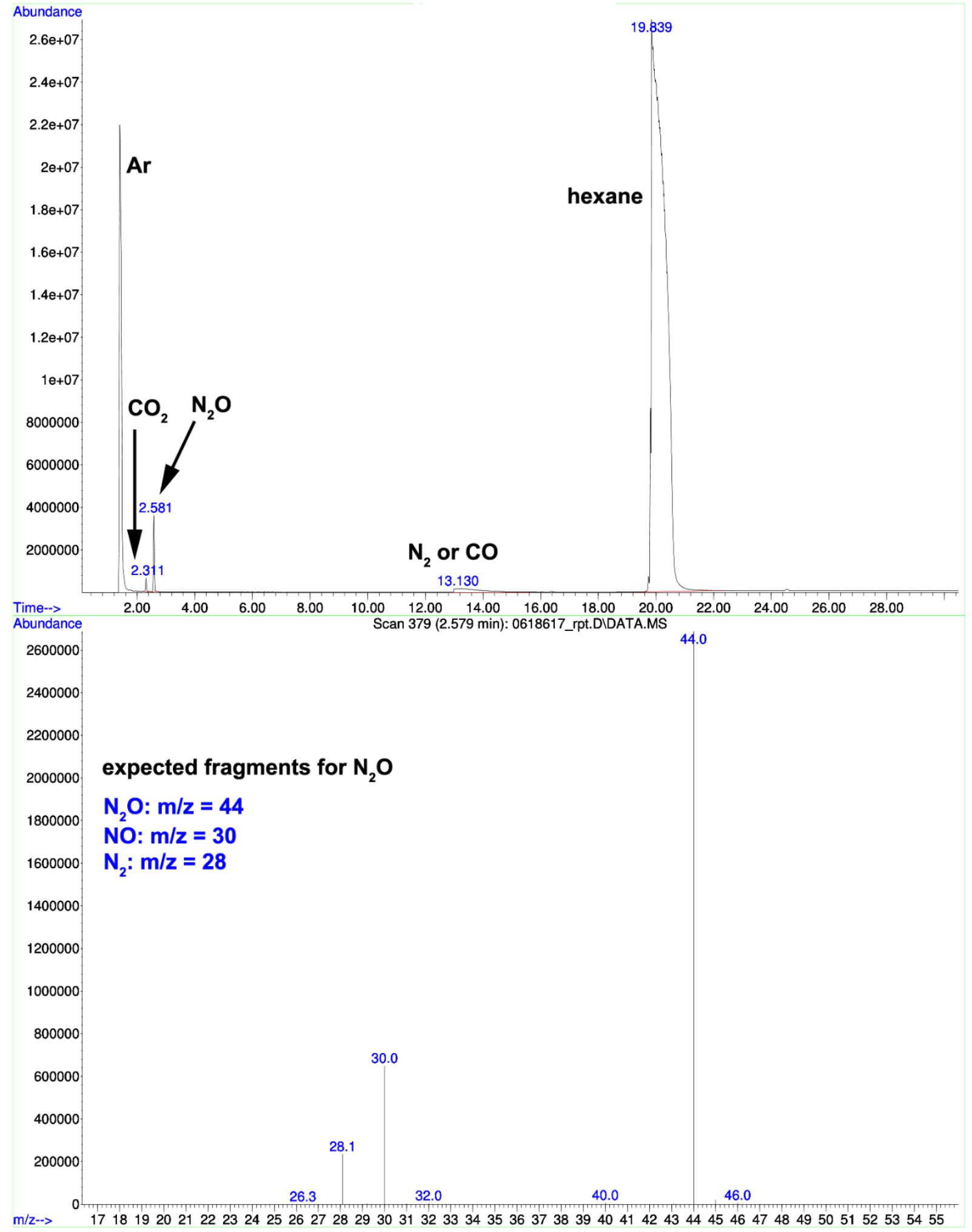

Figure S25. GC-MS analysis of the headspace gas obtained after stirring $\mathbf{3}_{\mathrm{Y}}$ at room temperature in hexane for approximately 120 hours. 


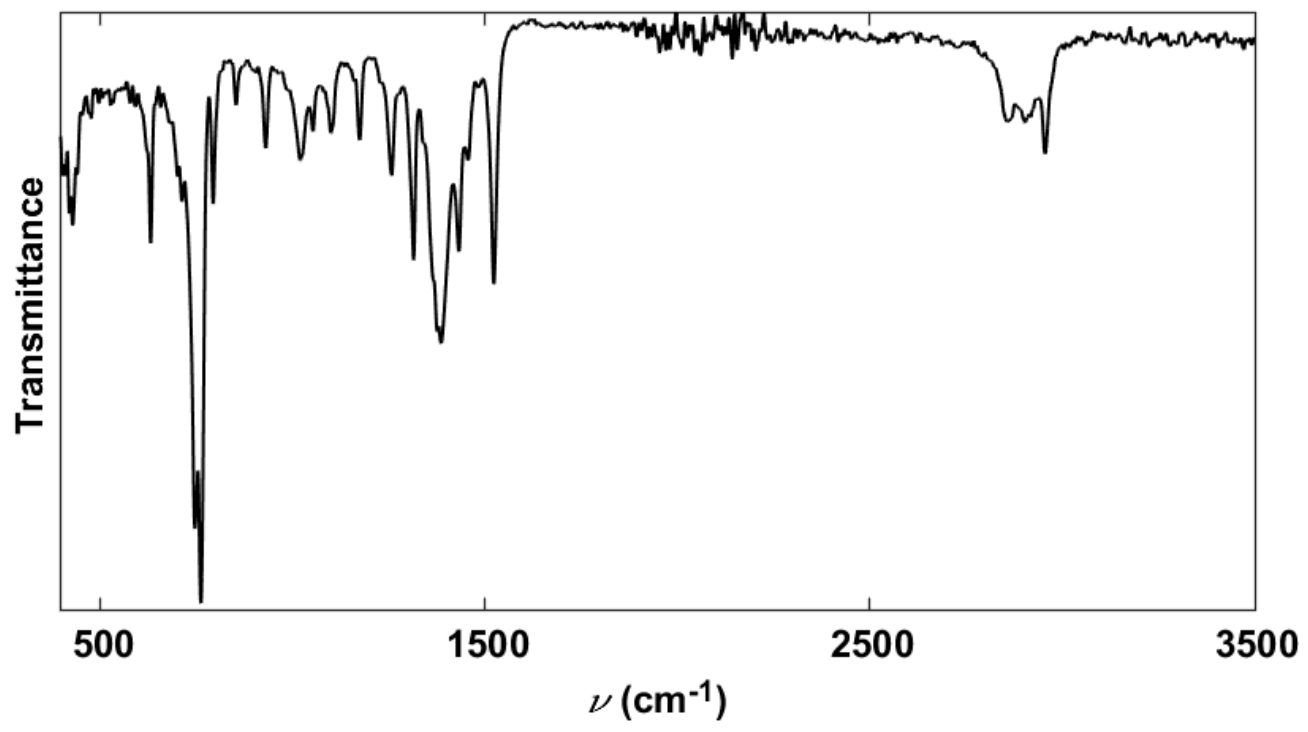

Figure S26. FTIR spectrum of $\left[\left(\mathrm{Cp}^{*}\right)_{2} \mathrm{YOFe}\left(\mathrm{L}^{\mathrm{Dipp}}\right)\right]\left(\mathbf{4}_{\mathbf{Y}}\right)$. 


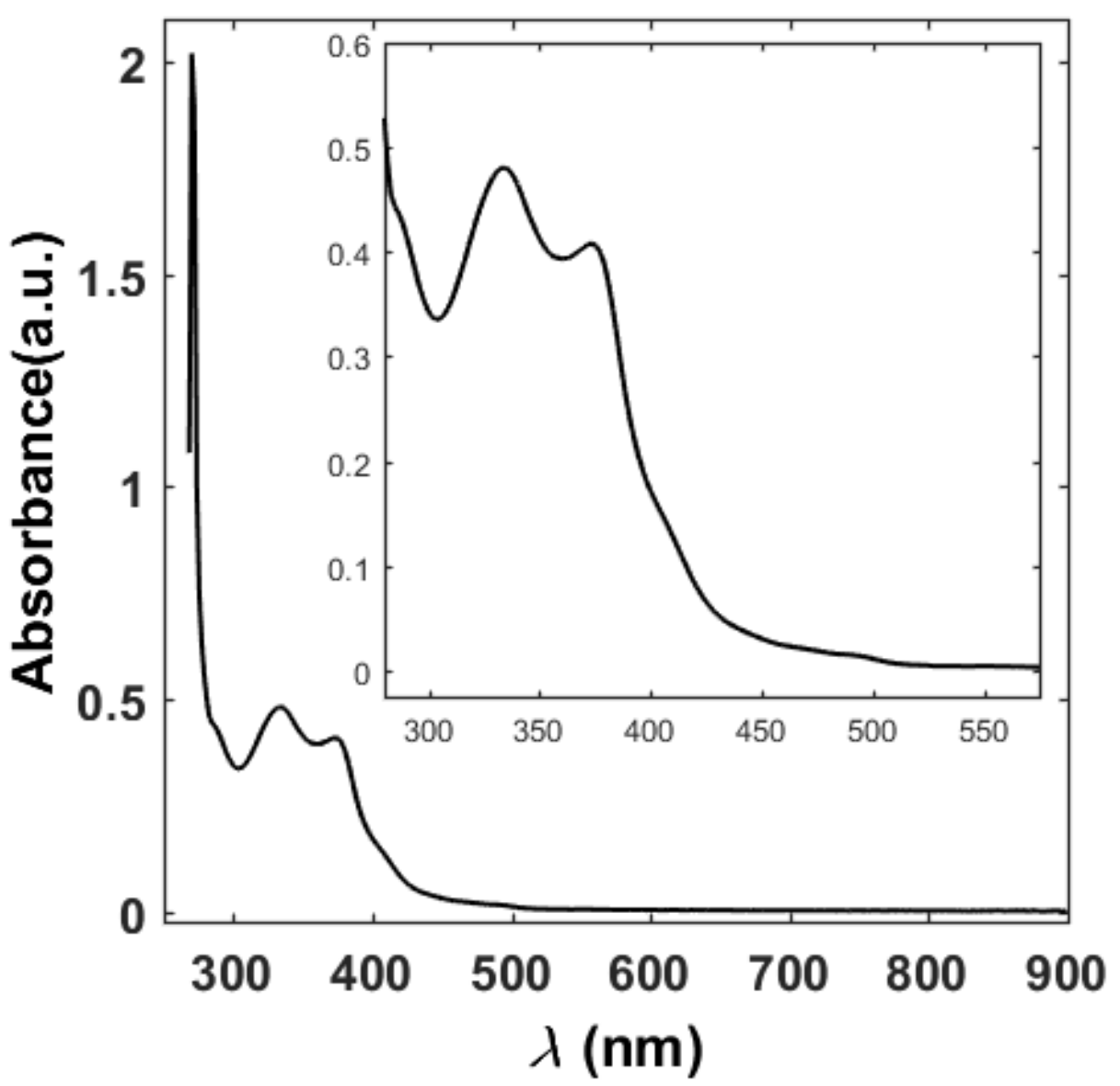

Figure S27. UV-vis spectrum of $\left[\left(\mathrm{Cp}^{*}\right)_{2} \mathrm{YOFe}\left(\mathrm{L}^{\mathrm{Dipp}}\right)\right]\left(\mathbf{4}_{\mathrm{Y}}\right)$ in toluene $(0.1 \mathrm{mM})$ at room temperature. 


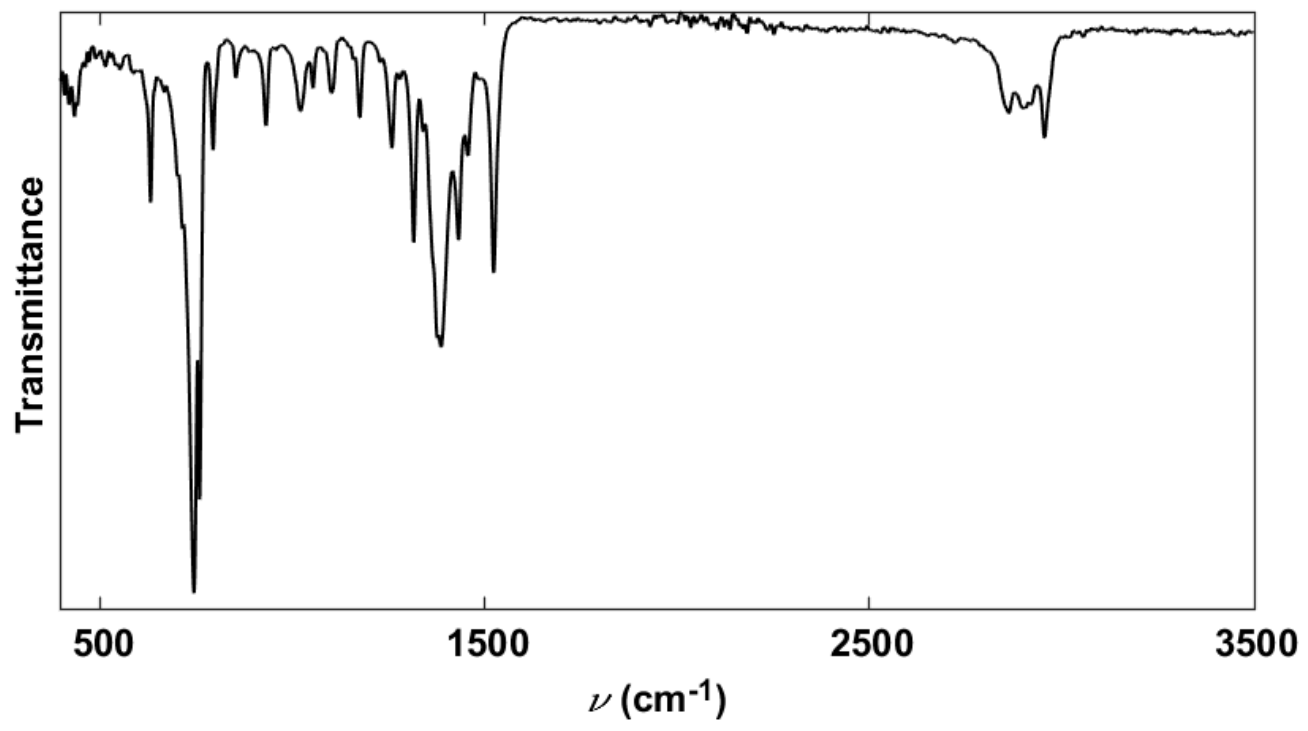

Figure S28. FTIR spectrum of $\left[\left(\mathrm{Cp}^{*}\right)_{2} \mathrm{GdOFe}\left(\mathrm{L}^{\mathrm{Dipp}}\right)\right]\left(\mathbf{4}_{\mathrm{Gd}}\right)$. 


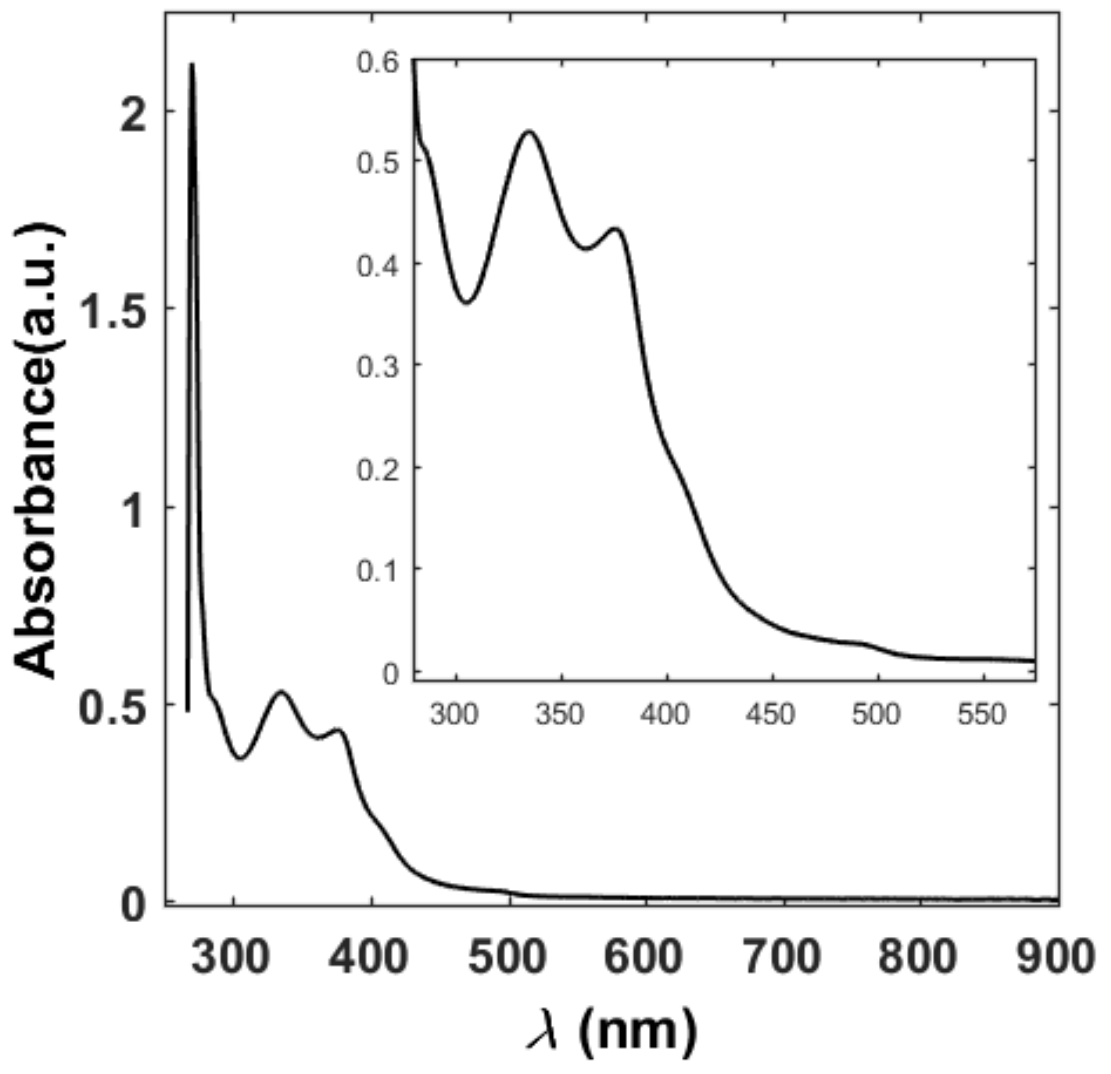

Figure S29. UV-vis spectrum of $\left[\left(\mathrm{Cp}^{*}\right)_{2} \mathrm{GdOFe}\left(\mathrm{L}^{\mathrm{Dipp}}\right)\right]\left(\mathbf{4}_{\mathrm{Gd}}\right)$ in toluene $(0.1 \mathrm{mM})$ at room temperature. 


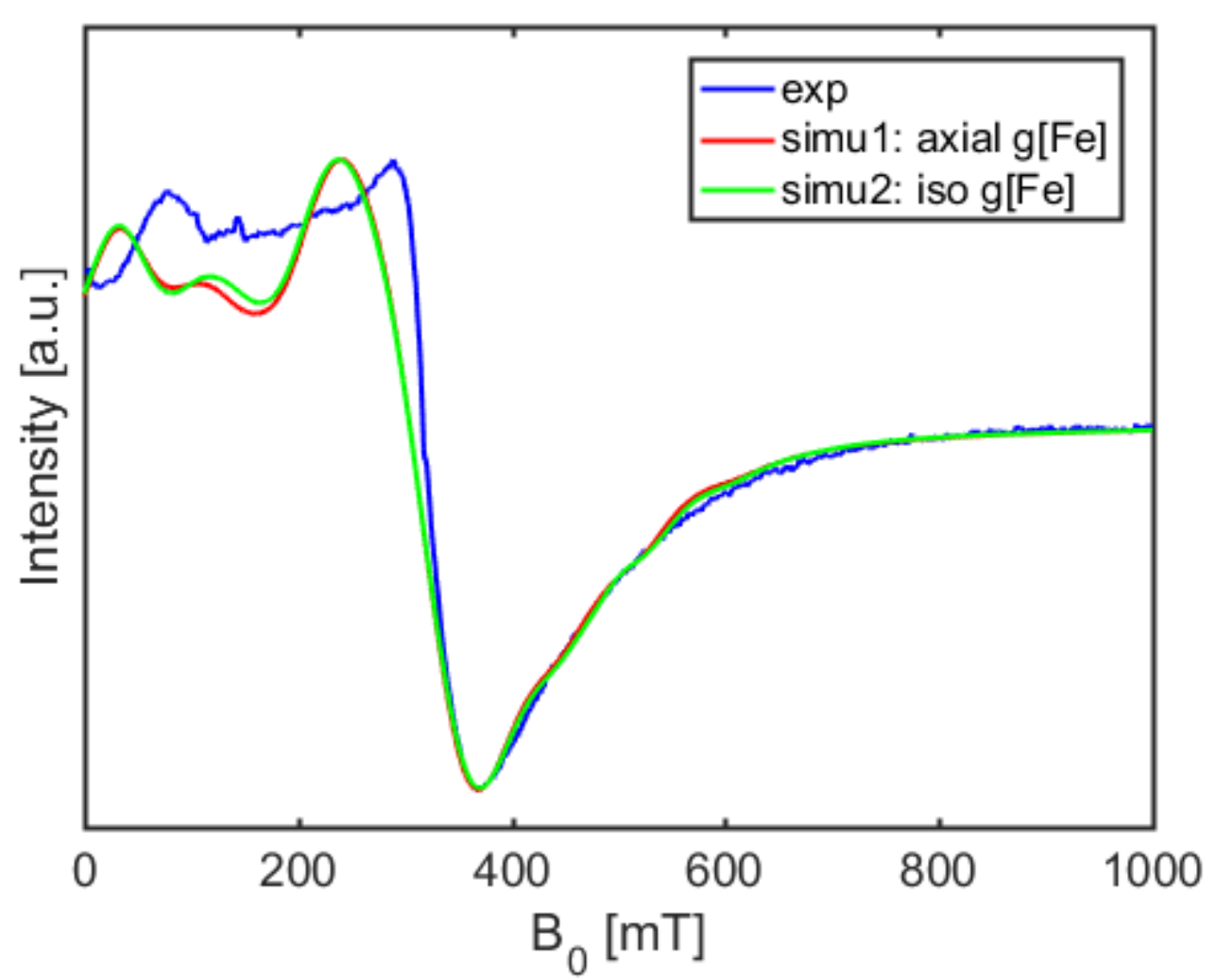

Figure S30. X-Band CW-EPR spectrum (dark blue line) recorded on a frozen toluene solution of $\left[\left(\mathrm{Cp}^{*}\right)_{2} \mathrm{GdOFe}\left(\mathrm{L}^{\mathrm{Dipp}}\right)\right]\left(\mathbf{4}_{\mathbf{G d}}\right)$ at $95 \mathrm{~K}$.

Simulation 1 (red line): Here, we considered two exchange-coupled spin centres, $\mathrm{Gd}^{3+}$ with $S=7 / 2$ and $\mathrm{Fe}^{2+}$ with $S=2$, with $J=+0.21 \mathrm{~cm}^{-1}$ and nuclear hyperfine interactions. An isotropic $g$-factor of 2.00 was used for $\mathrm{Gd}^{3+}$ and axial $g$-factors of $g_{x}=g_{y}=2.80$ and $g_{z}=1.75$ for Fe ${ }^{2+}$. The ZFS parameters are $D_{\mathrm{Fe}}=-15.6 \mathrm{~cm}^{-1}$ and $D_{\mathrm{Gd}}=0.046 \mathrm{~cm}^{-1},|E||| D \mid=0.33$ for $\mathrm{Gd}$ and 0.30 for Fe; and a Lorentzian linewidth of $65 \mathrm{mT}$.

Simulation 2 (green line): Here, we considered two exchange-coupled spin centres, $\mathrm{Gd}^{3+}$ with $S=7 / 2$ and $\mathrm{Fe}^{2+}$ with $S=2$, with $J=+0.21 \mathrm{~cm}^{-1}$ and nuclear hyperfine interactions. An isotropic $g$-factor of 2.00 was used for $\mathrm{Gd}^{3+}$ and an anisotropic $g$-factor of $g=2.488$ for $\mathrm{Fe}^{2+}$. The ZFS parameters are $D_{\mathrm{Fe}}=-15.6 \mathrm{~cm}^{-1}$ and $D_{\mathrm{Gd}}=0.046 \mathrm{~cm}^{-1},|E| /|D|=0.33$ for Gd and 0.30 for Fe; and a Lorentzian linewidth of $40 \mathrm{mT}$. 
X-ray crystallography: X-ray crystallographic data were collected at low temperature (100-150 K) using: a dual source Rigaku FR-X rotating anode diffractometer equipped with a HyPix $6000 \mathrm{HE}$ detector for $\mathbf{2}_{\mathrm{M}}$ and $\mathbf{3}_{\mathbf{M}}$; or an Agilent Supernova diffractometer for $\left[\left(\mathrm{L}^{\mathrm{Mes}}\right) \mathrm{Fe}(\mathrm{NO})_{2}\right], \mathbf{1 a}, \mathbf{4}_{\mathbf{Y}}$ and $\mathbf{4}_{\mathrm{Gd}}$ with an Enhance Ultra equipped with an Eos CCD area detector, operating in $\omega$ scanning mode to fill the Ewald sphere. Control, integration and absorption correction were handled by the CrysAlisPro software. The structures have been solved by direct methods using ShelxT and refined by means of least-square procedures on F using ShelxL embedded in Olex2 software package. ${ }^{5-7}$ Absorption correction was performed using a multi-scan procedure. All non-hydrogen atoms were refined anisotropically. The $\mathrm{H}$ atoms those are attached to the carbon atoms were repositioned geometrically. The $\mathrm{H}$ atoms were initially refined with soft restraints on the bond lengths and angles to regularise their geometry and $\mathrm{U} \sim \mathrm{iso} \sim(\mathrm{H})$ (in the range 1.2-1.5 times $\mathrm{U} \sim \mathrm{eq} \sim$ of the parent atom), after which the positions were refined with riding constraints.

Table S1. Crystal data and structure refinement parameters for $\left[\left(\mathrm{L}^{\mathrm{Mes}}\right) \mathrm{Fe}(\mathrm{NO})_{2}\right]$ and $\mathbf{1 a}$.

\begin{tabular}{|c|c|c|}
\hline & {$\left[\left(\mathbf{L}^{\mathrm{Mes}}\right) \mathbf{F e}(\mathbf{N O})_{2}\right]$} & $1 \mathbf{a}$ \\
\hline CCDC ref. code & 1909577 & 1909568 \\
\hline Formula & $\mathrm{C}_{23} \mathrm{H}_{29} \mathrm{FeN}_{4} \mathrm{O}_{2}$ & $\mathrm{C}_{39} \mathrm{H}_{65} \mathrm{FeN}_{5} \mathrm{O}_{2}$ \\
\hline FW & 449.35 & 691.81 \\
\hline Crystal system & monoclinic & triclinic \\
\hline Space group & $P 2_{1} / c$ & $P \overline{1}$ \\
\hline$a / \AA$ & $25.4275(18)$ & $11.5668(5)$ \\
\hline$b / \AA$ & $20.3332(4)$ & $12.4022(5)$ \\
\hline$c / \AA ̊$ & $15.0048(11)$ & $15.0090(8)$ \\
\hline$\alpha /^{\circ}$ & 90 & $100.604(4)$ \\
\hline$\beta 1^{\circ}$ & $142.261(15)$ & $111.178(4)$ \\
\hline$\gamma /{ }^{\circ}$ & 90 & $91.002(4)$ \\
\hline$V / \AA^{3}$ & $4748.3(17)$ & $1965.10(17)$ \\
\hline$Z$ & 8 & 2 \\
\hline Radiation type & $\mathrm{CuK}_{\alpha}$ & $\mathrm{MoK}_{\alpha}$ \\
\hline Wavelength $(\AA)$ & 1.54184 & 0.71073 \\
\hline Crystal dimensions/mm & $0.04 \times 0.02 \times 0.02$ & $0.20 \times 0.08 \times 0.06$ \\
\hline $2 \theta$ range $/^{\circ}$ & $2.839-63.65$ & $5.29-50.48$ \\
\hline Reflections collected & 7639 & 7183 \\
\hline Independent reflections & 6359 & 5774 \\
\hline Completeness $/ \%$ & 97.7 & 98.5 \\
\hline Data/restraints/parameters & $7639 / 0 / 551$ & $7183 / 0 / 424$ \\
\hline Goodness-of-fit on $F^{2}$ & 1.012 & 1.043 \\
\hline Final $R$ indices $[I>2 \sigma(I)]$ & 0.0403 & 0.0571 \\
\hline Final $R$ indices (all data) & 0.1009 & 0.1618 \\
\hline
\end{tabular}


Table S2. Crystal data and structure refinement for $\mathbf{2}_{\mathrm{M}}$.

\begin{tabular}{|c|c|c|}
\hline & $\mathbf{2}_{\mathbf{Y}}$ & $2_{\mathrm{Gd}}$ \\
\hline CCDC ref. code & 1909576 & 1909575 \\
\hline Formula & $\mathrm{C}_{43} \mathrm{H}_{59} \mathrm{FeN}_{4} \mathrm{O}_{2} \mathrm{Y}$ & $\mathrm{C}_{43} \mathrm{H}_{59} \mathrm{FeGdN}_{4} \mathrm{O}_{2}$ \\
\hline FW & 808.7 & 877.04 \\
\hline Crystal system & Orthorhombic & Orthorhombic \\
\hline Space group & $P 2_{1} 2_{1} 2_{1}$ & $P 2_{1} 2_{1} 2_{1}$ \\
\hline$a / \AA$ & $8.6617(1)$ & $8.6849(2)$ \\
\hline$b / \AA$ & $21.2088(1)$ & $21.2561(3)$ \\
\hline$c / \AA$ & $22.7976(1)$ & $22.8285(4)$ \\
\hline$\alpha /^{\circ}$ & 90 & 90 \\
\hline$\beta /^{\circ}$ & 90 & 90 \\
\hline$\gamma /{ }^{\circ}$ & 90 & 90 \\
\hline$V / \AA^{3}$ & $4188.02(6)$ & $4214.30(14)$ \\
\hline$Z$ & 4 & 4 \\
\hline Radiation type & $\mathrm{CuK}_{\alpha}$ & $\mathrm{CuK}_{\alpha}$ \\
\hline Wavelength $(\AA)$ & 1.54184 & 1.54184 \\
\hline Crystal dimensions/mm & $0.15 \times 0.02 \times 0.02$ & $0.20 \times 0.05 \times 0.02$ \\
\hline $2 \theta \mathrm{range}^{\circ}$ & $2.85-67.84$ & $6.4-67.07$ \\
\hline Reflections collected & 7576 & 7360 \\
\hline Independent reflections & 7405 & 6842 \\
\hline Completeness $/ \%$ & 99.3 & 97.5 \\
\hline Data/restraints/parameters & $7576 / 0 / 508$ & $7360 / 0 / 490$ \\
\hline Goodness-of-fit on $F^{2}$ & 0.998 & 0.932 \\
\hline Final $R$ indices $[I>2 \sigma(I)]$ & 0.026 & 0.0381 \\
\hline Final $R$ indices (all data) & 0.0677 & 0.1216 \\
\hline
\end{tabular}


Table S3. Crystal data and structure refinement for $\mathbf{3}_{\mathrm{M}}$.

\begin{tabular}{|c|c|c|}
\hline & $\mathbf{3}_{\mathbf{Y}}$ & $3_{\mathrm{Gd}}$ \\
\hline CCDC ref. code & 1909570 & 1909571 \\
\hline Formula & $\mathrm{C}_{49} \mathrm{H}_{71} \mathrm{FeN}_{4} \mathrm{O}_{2} \mathrm{Y}$ & $\mathrm{C}_{54} \mathrm{H}_{83} \mathrm{FeGdN}_{4} \mathrm{O}_{2}$ \\
\hline FW & 892.86 & 1033.34 \\
\hline Crystal system & triclinic & triclinic \\
\hline Space group & $P \overline{1}$ & $P \overline{1}$ \\
\hline$a / \AA$ & $14.1543(8)$ & $14.1740(3)$ \\
\hline$b / \AA$ & $19.3278(8)$ & $19.2468(4)$ \\
\hline$c / \AA$ & 21.0046(9) & $20.8800(4)$ \\
\hline$\alpha /^{\circ}$ & $100.680(4)$ & $100.408(2)$ \\
\hline$\beta /^{\circ}$ & $109.484(5)$ & $109.137(2)$ \\
\hline$\gamma / /^{\circ}$ & $92.982(4)$ & $93.002(2)$ \\
\hline$V / \AA^{3}$ & $5283.0(5)$ & $5254.5(2)$ \\
\hline$Z$ & 4 & 4 \\
\hline Radiation type & $\mathrm{CuK}_{\alpha}$ & $\mathrm{CuK}_{\alpha}$ \\
\hline Wavelength $(\AA)$ & 1.54184 & 1.54184 \\
\hline Crystal dimensions/mm & $0.12 \times 0.02 \times 0.01$ & $0.10 \times 0.08 \times 0.01$ \\
\hline $2 \theta$ range $/^{\circ}$ & $3.34-67.08$ & $2.29-67.08$ \\
\hline Reflections collected & 18694 & 18556 \\
\hline Independent reflections & 12461 & 16388 \\
\hline Completeness/\% & 99.1 & 99 \\
\hline Data/restraints/parameters & $18694 / 0 / 1067$ & $18556 / 0 / 1154$ \\
\hline Goodness-of-fit on $F^{2}$ & 0.956 & 1.011 \\
\hline Final $R$ indices $[>2 \sigma(I)]$ & 0.0594 & 0.034 \\
\hline Final $R$ indices (all data) & 0.1449 & 0.0869 \\
\hline
\end{tabular}


Table S4. Crystal data and structure refinement for $\mathbf{4}_{\mathrm{M}}$.

\begin{tabular}{lll}
\hline & $\mathbf{4}_{\mathbf{Y}}$ & $\mathbf{4}_{\mathbf{G d}}$ \\
\hline CCDC ref. code & 1909572 & 1909574 \\
Formula & $\mathrm{C}_{49} \mathrm{H}_{71} \mathrm{FeN}_{2} \mathrm{OY}$ & $\mathrm{C}_{49} \mathrm{H}_{71} \mathrm{FeN}{ }_{2} \mathrm{OGd}$ \\
$\mathrm{FW}$ & 848.84 & 917.18 \\
Crystal system & monoclinic & monoclinic \\
Space group & $C 2 / c$ & $C 2 / c$ \\
$a / \AA$ & $19.1390(11)$ & $19.1089(10)$ \\
$b / \AA$ & $23.753(3)$ & $23.798(2)$ \\
$c / \AA$ & $10.2240(7)$ & $10.2583(9)$ \\
$\alpha /^{\circ}$ & 90 & 90 \\
$\beta /^{\circ}$ & $97.911(7)$ & $97.357(6)$ \\
$\gamma /{ }^{\circ}$ & 90 & 90 \\
$V / \AA^{3}$ & $4603.7(7)$ & $4626.6(6)$ \\
$Z$ & 4 & 4 \\
Radiation type & $\mathrm{MoK}_{\alpha}$ & $\mathrm{MoK} \alpha$ \\
Wavelength $(\AA)$ & 0.71073 & 0.71073 \\
Crystal dimensions/mm & $0.20 \times 0.10 \times 0.01$ & $0.20 \times 0.15 \times 0.02$ \\
$2 \theta$ range ${ }^{\circ}$ & $6.25-50.48$ & $6.46-52.74$ \\
Reflections collected & 4611 & 4691 \\
Independent reflections & 2404 & 3293 \\
Completeness/\% & 98.1 & 99 \\
Data/restraints/parameters & $4611 / 0 / 248$ & $4691 / 0 / 245$ \\
Goodness-of-fit on $F^{2}$ & 1 & 1.082 \\
Final $R$ indices [ $\$>2 \sigma(I)]$ & 0.0877 & 0.0759 \\
Final $R$ indices (all data) & 0.2189 & 0.1687 \\
\hline & & \\
& &
\end{tabular}




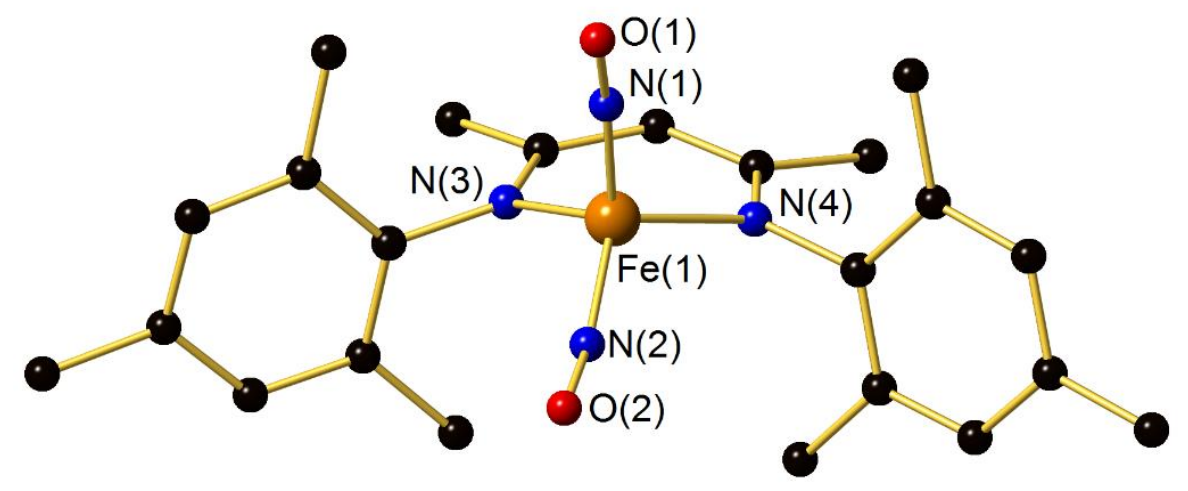

Figure S31. Molecular structure of one molecule of $\left[\left(\mathrm{L}^{\mathrm{Mes}}\right) \mathrm{Fe}(\mathrm{NO})_{2}\right]$. $\mathrm{H}$ atoms are omitted for clarity. Selected bond lengths $(\AA)$ and angles $\left(^{\circ}\right)$ : $\mathrm{Fe}(2)-\mathrm{N}(8), 1.968(2)$; $\mathrm{Fe}(2)-\mathrm{N}(7), 1.958(2) ; \mathrm{Fe}(2)-\mathrm{N}(6), 1.690(2)$; $\mathrm{Fe}(2)-\mathrm{N}(5), 1.693(3) ; \mathrm{Fe}(1)-\mathrm{N}(4), 1.966(2) ; \mathrm{Fe}(1)-\mathrm{N}(3), 1.979(2) ; \mathrm{Fe}(1)-\mathrm{N}(2), 1.697(3) ; \mathrm{Fe}(1)-\mathrm{N}(1)$, 1.679(3); O(4)-N(6), 1.161(3); O(3)-N(5), 1.130(3); O(1)-N(2), 1.169(3); O(2)-N(1), 1.158(3); N(7)-Fe(2)$\mathrm{N}(8), 94.62(8) ; \mathrm{N}(6)-\mathrm{Fe}(2)-\mathrm{N}(8), 111.78(10) ; \mathrm{N}(6)-\mathrm{Fe}(2)-\mathrm{N}(7), 111.73(10) ; \mathrm{N}(6)-\mathrm{Fe}(2)-\mathrm{N}(5), 111.72(12)$; $\mathrm{N}(5)-\mathrm{Fe}(2)-\mathrm{N}(8), 112.10(10) ; \mathrm{N}(5)-\mathrm{Fe}(2)-\mathrm{N}(7), 113.83(11) ; \mathrm{N}(4)-\mathrm{Fe}(1)-\mathrm{N}(3), 95.22(8) ; \mathrm{N}(2)-\mathrm{Fe}(1)-\mathrm{N}(4)$, 110.34(10); N(2)-Fe(1)-N(3), 113.91(10); N(1)-Fe(1)-N(4), 112.30(11); N(1)-Fe(1)-N(3), 112.66(11); N(1)$\mathrm{Fe}(1)-\mathrm{N}(2), 111.45(13) ; \mathrm{O}(4)-\mathrm{N}(6)-\mathrm{Fe}(2), 163.2(2) ; \mathrm{O}(1)-\mathrm{N}(2)-\mathrm{Fe}(1), 159.6(3) ; \mathrm{O}(3)-\mathrm{N}(5)-\mathrm{Fe}(2), 165.4(2)$.

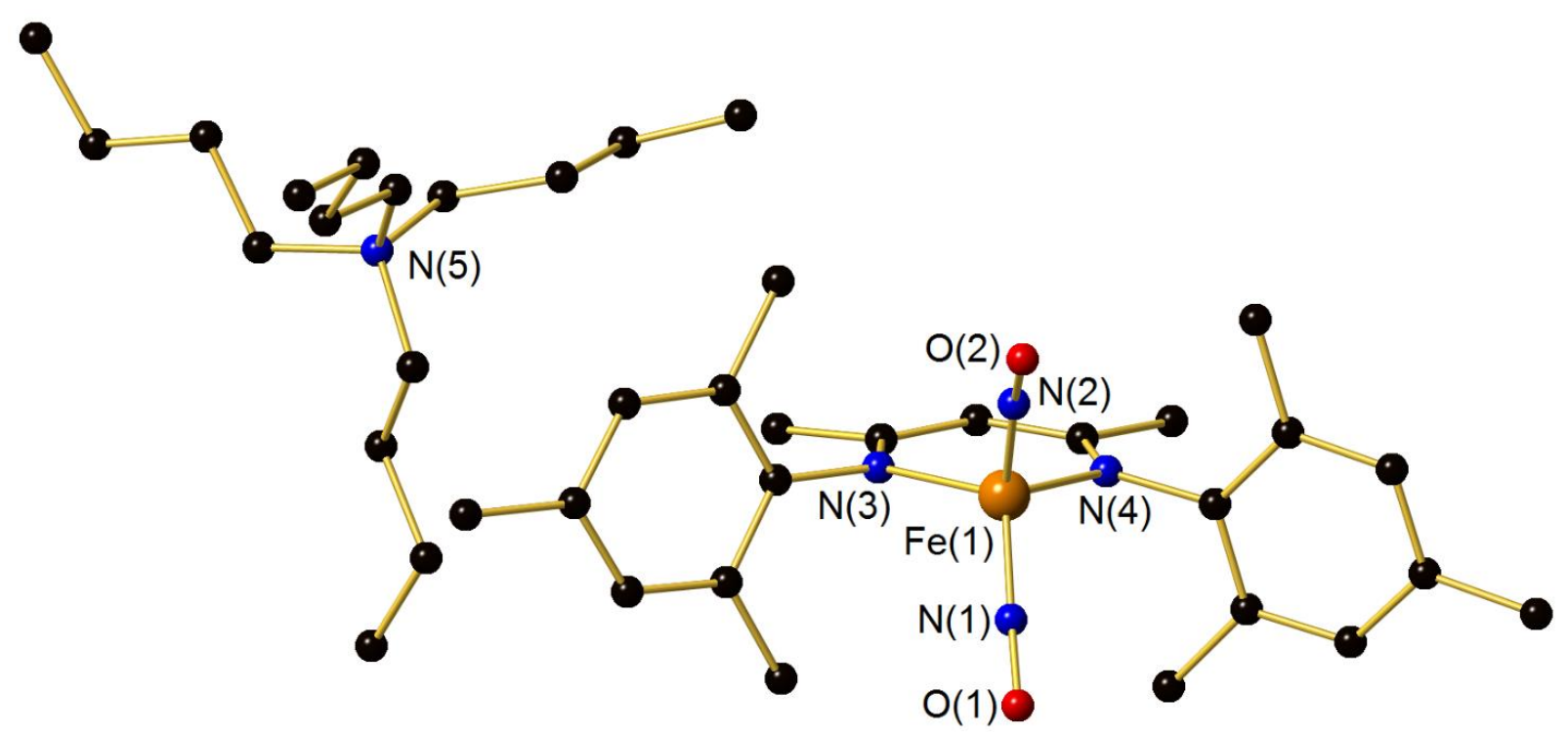

Figure S32. Molecular structure of $\left[\mathrm{Bu}_{4} \mathrm{~N}\right]\left[\left(\mathrm{L}^{\mathrm{Mes}}\right) \mathrm{Fe}(\mathrm{NO})_{2}\right](\mathbf{1 a})$. $\mathrm{H}$ atoms are omitted for clarity. Selected bond lengths $(\AA)$ and angles $\left(^{\circ}\right)$ : $\mathrm{Fe}(1)-\mathrm{N}(4), 2.0200(19) ; \mathrm{Fe}(1)-\mathrm{N}(3), 2.0171(19) ; \mathrm{Fe}(1)-\mathrm{N}(1), 1.645(2)$; $\mathrm{Fe}(1)-\mathrm{N}(2), 1.653(2) ; \mathrm{O}(1)-\mathrm{N}(1), 1.216(2) ; \mathrm{O}(2)-\mathrm{N}(2), 1.213(3) ; \mathrm{N}(3)-\mathrm{Fe}(1)-\mathrm{N}(4), 89.44(8) ; \mathrm{N}(1)-\mathrm{Fe}(1)-$ $\mathrm{N}(4), 114.16(9) ; \mathrm{N}(1)-\mathrm{Fe}(1)-\mathrm{N}(3), 111.53(9) ; \mathrm{N}(1)-\mathrm{Fe}(1)-\mathrm{N}(2), 113.23(10) ; \mathrm{N}(2)-\mathrm{Fe}(1)-\mathrm{N}(4), 112.11(9)$; $\mathrm{N}(2)-\mathrm{Fe}(1)-\mathrm{N}(3), 114.29(9) ; \mathrm{O}(1)-\mathrm{N}(1)-\mathrm{Fe}(1), 170.81(18) ; \mathrm{O}(2)-\mathrm{N}(2)-\mathrm{Fe}(1), 163.18(19)$. 


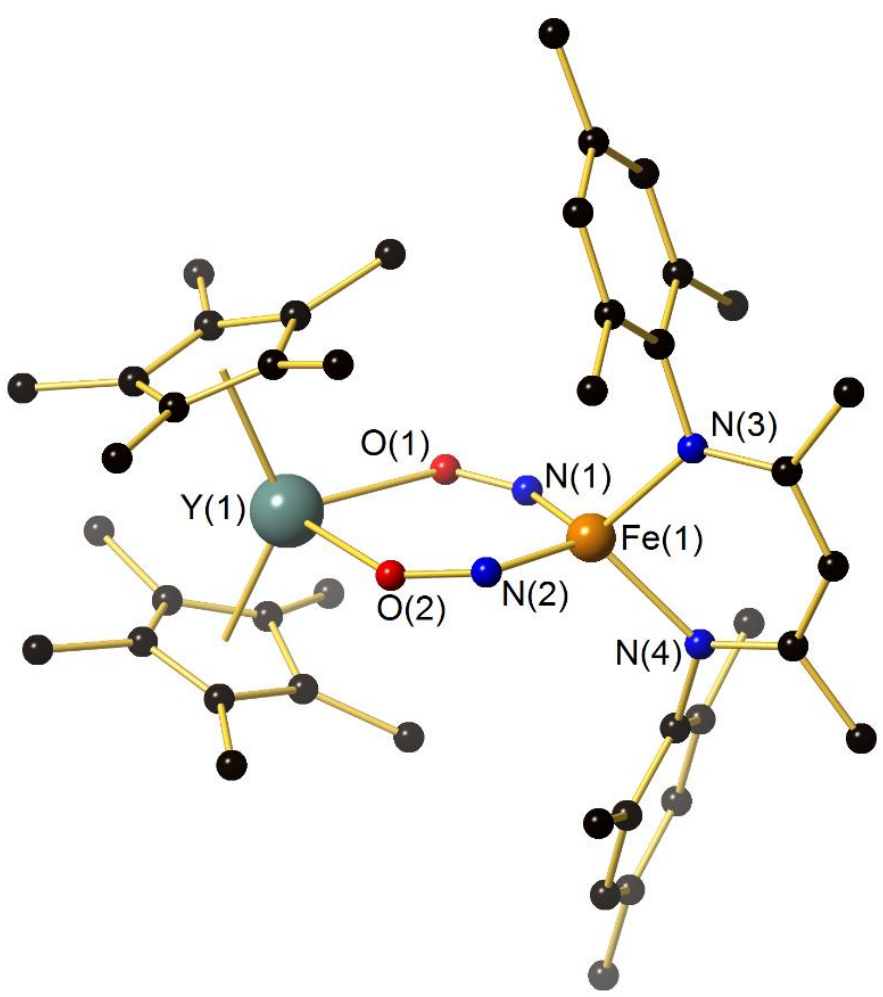

Figure S33. Molecular structure of $\left[\left(\mathrm{Cp}^{*}\right)_{2} \mathrm{Y}(\mathrm{ON})_{2} \mathrm{Fe}\left(\mathrm{L}^{\mathrm{Mes}}\right)\right]\left(\mathbf{2}_{\mathrm{Y}}\right)$. The $\mathrm{H}$ atoms are omitted for clarity. Selected bond lengths $(\AA)$ and angles $\left({ }^{\circ}\right)$ : $\mathrm{Fe}(1)-\mathrm{N}(1), 1.660(3) ; \mathrm{Fe}(1)-\mathrm{N}(2), 1.646(2) ; \mathrm{N}(1)-\mathrm{O}(1), 1.252(3)$; $\mathrm{N}(2)-\mathrm{O}(2), 1.244(3) ; \mathrm{Y}(1)-\mathrm{O}(1), 2.328(2) ; \mathrm{Y}(1)-\mathrm{O}(2), 2.361(2) ; \mathrm{Y}(1)-\mathrm{Cp}, 2.305,2.343 ; \mathrm{N}(1)-\mathrm{Fe}(1)-\mathrm{N}(2)$, 93.96(12); $\mathrm{Fe}(1)-\mathrm{N}(1)-\mathrm{O}(1), 145.4(2)$; N(1)-O(1)-Y(1), 125.79(17); O(1)-Y(1)-O(2), 82.42(7); $\mathrm{Y}(1)-\mathrm{O}(2)-$ $\mathrm{N}(2), 120.46(19) ; \mathrm{O}(2)-\mathrm{N}(2)-\mathrm{Fe}(1), 151.9(2) ; \mathrm{Cp}-\mathrm{Y}(1)-\mathrm{Cp}, 135.34$. 


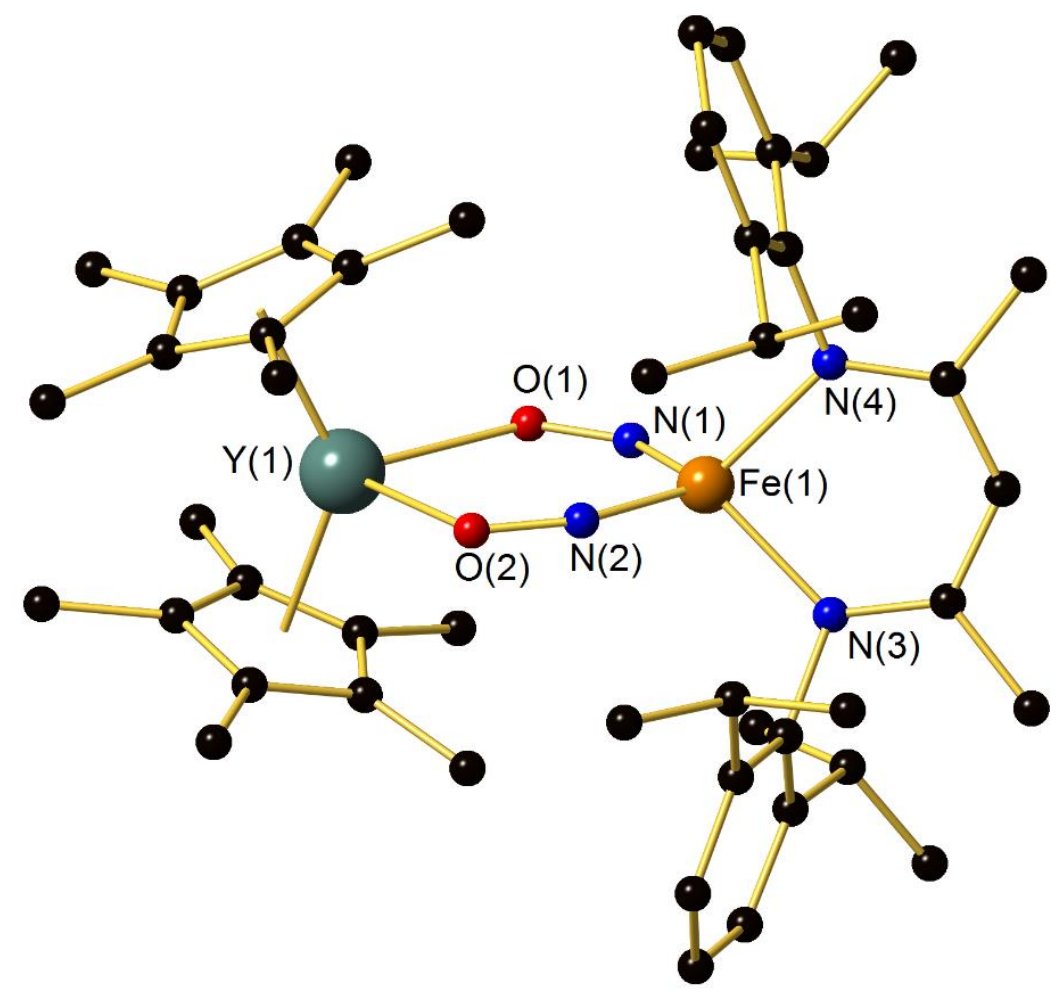

Figure S34. Molecular structure of $\left[\left(\mathrm{Cp}^{*}\right)_{2} \mathrm{Y}(\mathrm{ON})_{2} \mathrm{Fe}\left(\mathrm{L}^{\mathrm{Dipp}}\right)\right]\left(\mathbf{3}_{\mathrm{Y}}\right)$. The $\mathrm{H}$ atoms are omitted for clarity. Selected bond lengths $(\AA)$ and angles $\left({ }^{\circ}\right)$ : $\mathrm{Fe}(1)-\mathrm{N}(1), 1.647(4) ; \mathrm{Fe}(1)-\mathrm{N}(2), 1.669(4) ; \mathrm{N}(1)-\mathrm{O}(1), 1.231(5)$; $\mathrm{N}(2)-\mathrm{O}(2), 1.243(5) ; \mathrm{Y}(1)-\mathrm{O}(1), 2.368(4) ; \mathrm{Y}(1)-\mathrm{O}(2), 2.327(4) ; \mathrm{Y}(1)-\mathrm{Cp}, 2.329,2.342 ; \mathrm{N}(1)-\mathrm{Fe}(1)-\mathrm{N}(2)$, 91.96(19); $\mathrm{Fe}(1)-\mathrm{N}(1)-\mathrm{O}(1), 152.5(2) ; \mathrm{N}(1)-\mathrm{O}(1)-\mathrm{Y}(1), 123.0(3) ; \mathrm{O}(1)-\mathrm{Y}(1)-\mathrm{O}(2), 78.65(12) ; \mathrm{Y}(1)-\mathrm{O}(2)-$ $\mathrm{N}(2), 130.5(3) ; \mathrm{O}(2)-\mathrm{N}(2)-\mathrm{Fe}(1), 143.1(4) ; \mathrm{Cp}-\mathrm{Y}(1)-\mathrm{Cp}, 134.42$. 


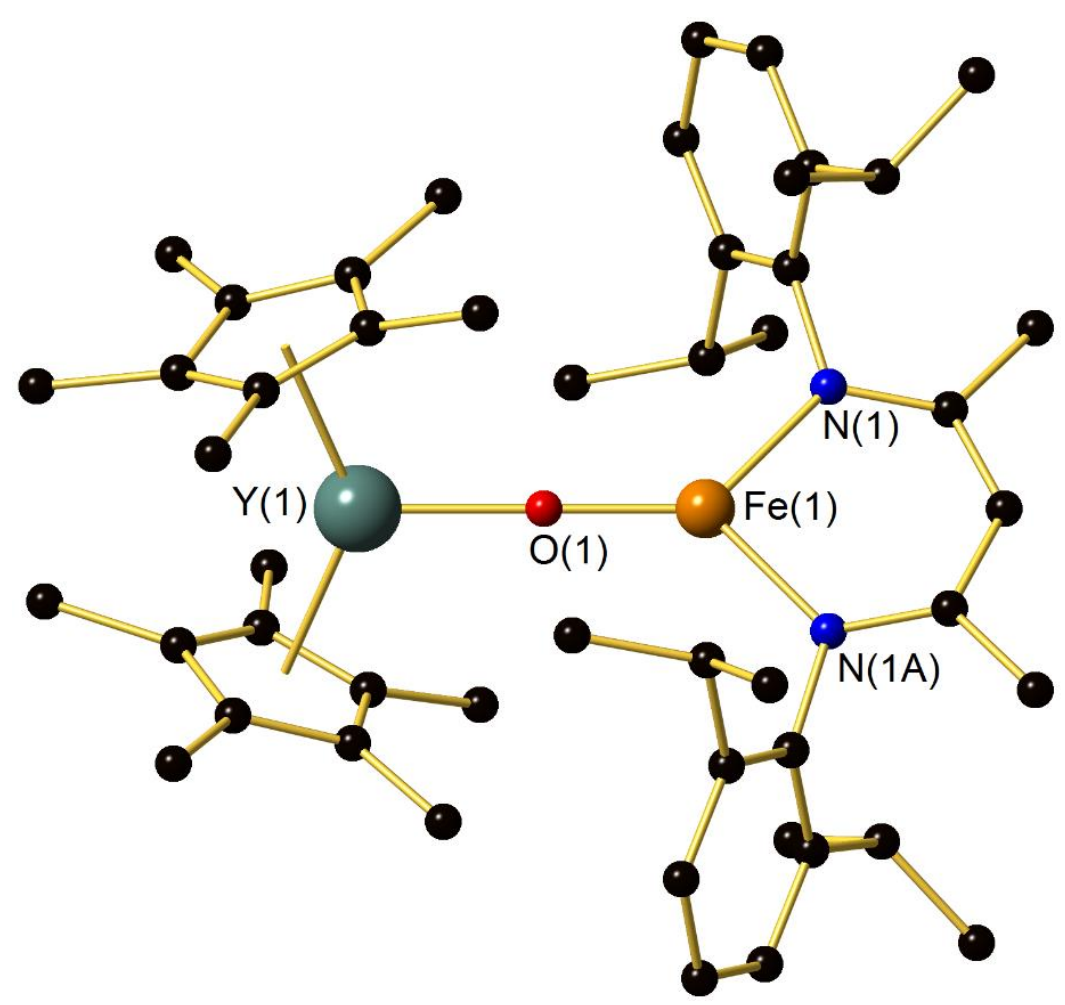

Figure S35. Molecular structure of $\left[\left(\mathrm{Cp}^{*}\right)_{2} \mathrm{YOFe}\left(\mathrm{L}^{\mathrm{Dipp}}\right)\right]\left(\mathbf{4}_{\mathrm{Y}}\right)$. The $\mathrm{H}$ atoms are omitted for clarity. Selected bond lengths $(\AA)$ and angles $\left({ }^{\circ}\right)$ : $\mathrm{Y}(1)-\mathrm{O}(1), 2.040(8)$; $\mathrm{Fe}(1)-\mathrm{O}(1), 1.769(8) ; \mathrm{Fe}(1)-\mathrm{N}(1 \mathrm{~A}), 2.010(5)$; $\mathrm{Fe}(1)-$ $\mathrm{N}(1), 2.010(5) ; \mathrm{O}(1)-\mathrm{Fe}(1)-\mathrm{N}(1 \mathrm{~A}), 132.34(15) ; \mathrm{O}(1)-\mathrm{Fe}(1)-\mathrm{N}(1), 132.34(15) ; \mathrm{N}(1)-\mathrm{Fe}(1)-\mathrm{N}(1 \mathrm{~A}), 95.3(3)$; $\mathrm{Fe}(1)-\mathrm{O}(1)-\mathrm{Y}(1), 180.0$. 
Magnetic property studies: Magnetic properties were investigated on polycrystalline solid samples of the complexes that were mixed with molten eicosane and sealed in a 7mm NMR tube under an argon atmosphere. Magnetic susceptibility measurements were carried out with a Quantum Design MPMS-5S SQUID susceptometer. The dc measurements were conducted from 300 to $2 \mathrm{~K}$ at $1000 \mathrm{Oe}(0.1 \mathrm{~T})$ and the data were corrected for the diamagnetism with Pascal's constants. ${ }^{8}$ The field dependence of the magnetization was measured at several temperatures between 2 and $7 \mathrm{~K}$ with dc magnetic fields up to $7 \mathrm{~T}$. Magnetic data were fitted using the spin Hamiltonians as coded in the PHI software. ${ }^{9}$

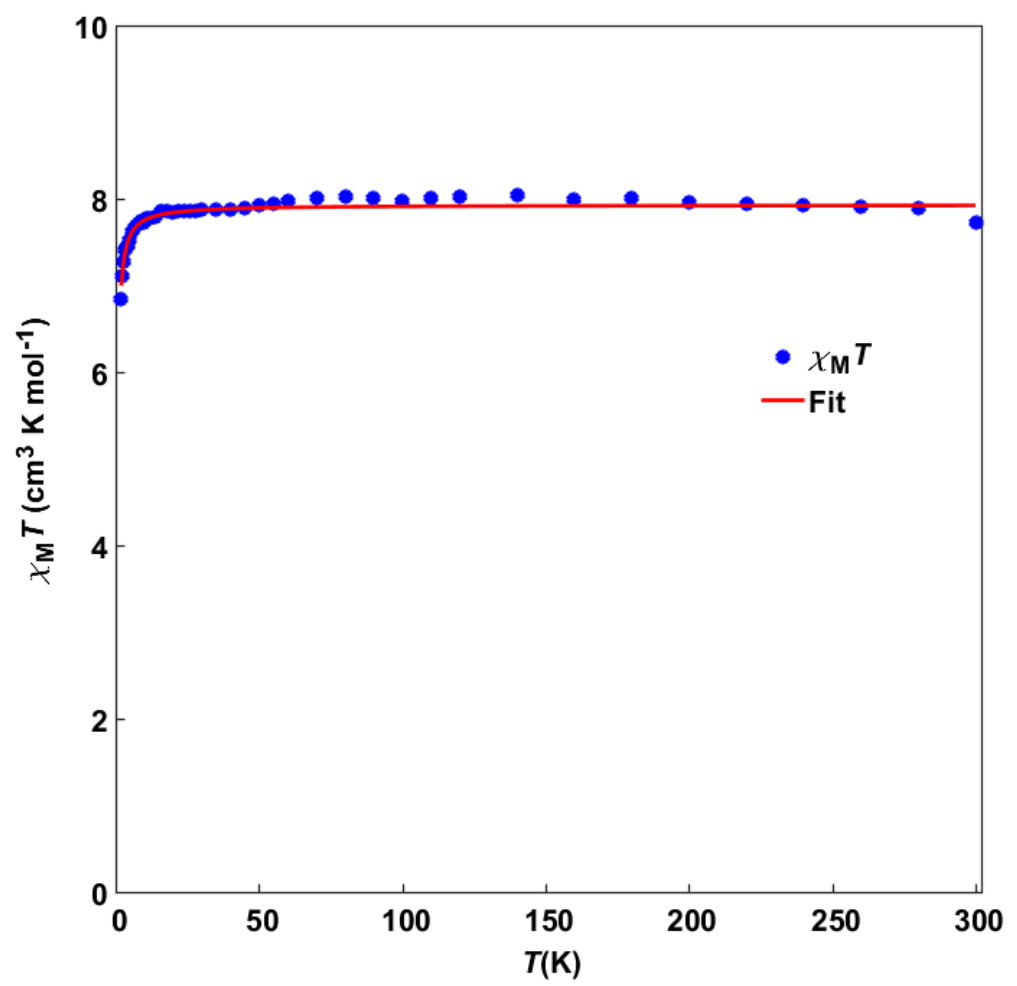

Figure S36. Plot of $\chi_{\mathrm{M}} T(T)$ (blue circles) with best fit (red line) in an applied field of $1000 \mathrm{Oe}(0.1 \mathrm{~T})$ for $\mathbf{2}_{\mathbf{G d}}$. The spin Hamiltonian used for the fit is: $\widehat{H}=\sum_{i=G d} \sum_{k=2} \sum_{q=-k}^{k} B_{k_{i}}^{q} \theta_{k} \hat{O}_{k_{i}}^{q}+\mu_{B} \sum\left(\overrightarrow{\hat{S}}_{i} \cdot \overline{\bar{g}}_{l}\right) \cdot \vec{B}$. The first part describes the crystal-field potential. $B_{k}^{q}$ are the crystal-field parameters of rank $k$ and order $q$ ( $-k$ to $+k) ; \theta_{k}$ are operator equivalent factors and $\hat{O}_{k}^{q}$ are the operator equivalents derived from the tesseral harmonics. The second order crystal-field operators are equated to the standard zero-field splitting spin Hamiltonian using the Abragam and Bleaney definitions, where the axial zero-field splitting parameter, $\mathrm{D}=$ $B_{2}^{0} \theta_{2}$. The second part is the Zeeman Hamiltonian, which allows the description of the magnetic properties based on first principles. $\overrightarrow{\hat{S}}$ is the spin vector of gadolinium, $\overline{\overline{g_{l}}}$ is the $g$-tensor, $\vec{B}$ is the applied magnetic field and $\mu_{B}$ is the Bohr magneton per mole. The data fit included a mean-field intermolecular superexchange interaction, $z J=-0.00725 \mathrm{~cm}^{-1}$ and a ZFS parameter $B_{2}^{0} \theta_{2}=-0.21 \mathrm{~cm}^{-1}$ with $0.005 \mathrm{~cm}^{-1}$ constrain. The best fits yielded $g_{\text {iso }}=2.006(2)$. 


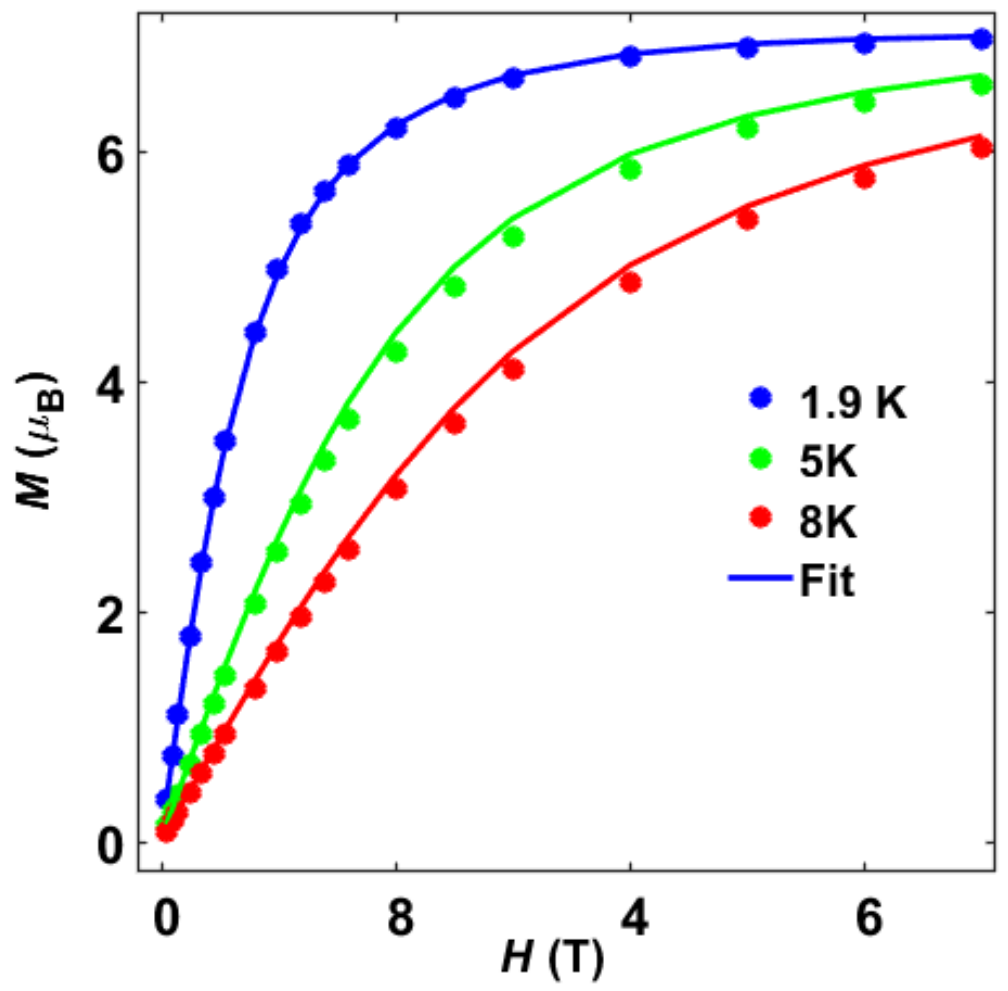

Figure S37. Plot of $M(H)$ (solid circles) with the best fits (solid lines) at $1.9 \mathrm{~K}, 5 \mathrm{~K}$ and $8 \mathrm{~K}$ for $\mathbf{2}_{\mathrm{Gd}}$. The fitting parameters are as described in the caption of Figure S36. 


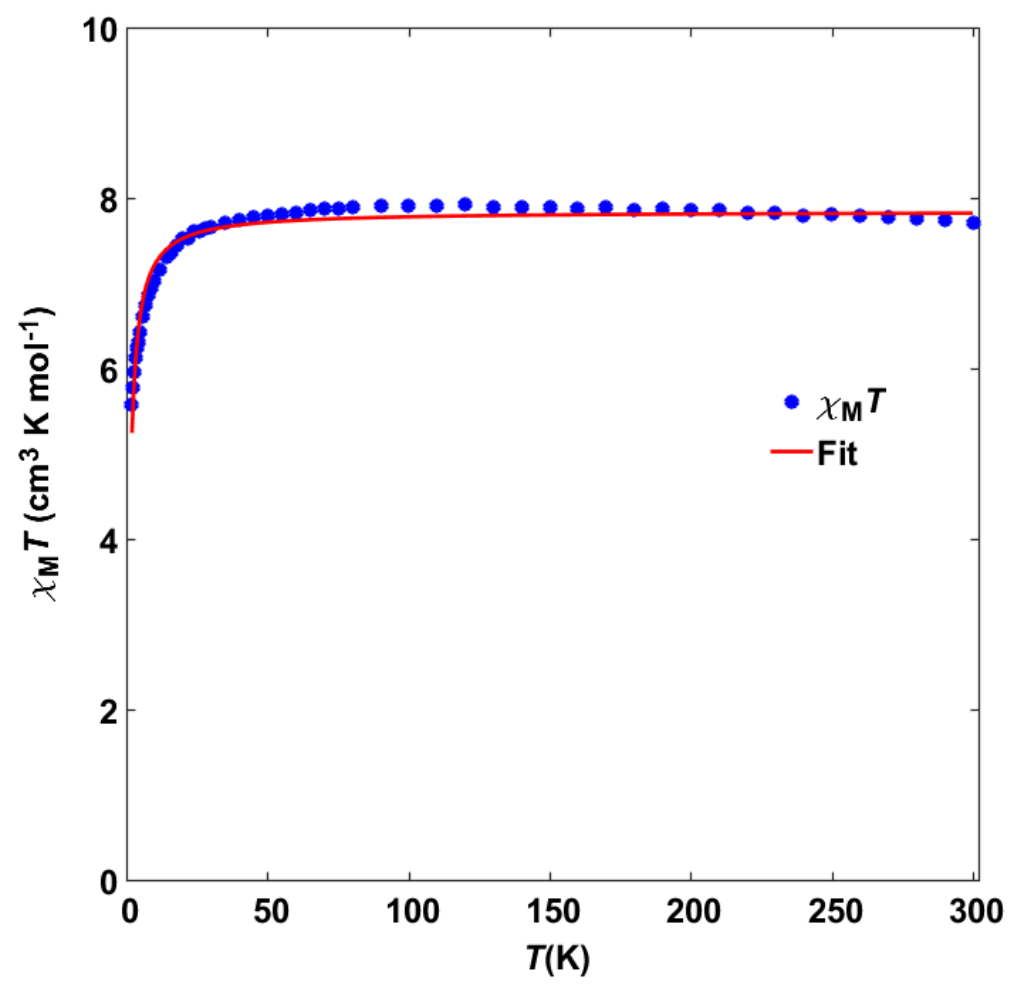

Figure S38. Plot of $\chi_{\mathrm{M}} T(T)$ (solid blue circles) with best fit (solid red line, same method as for $\mathbf{2}_{\mathrm{Gd}}$ ) in an applied field of $1000 \mathrm{Oe}(0.1 \mathrm{~T})$ for $\mathbf{3}_{\mathbf{G d}}$. The data fit included a mean-field intermolecular super-exchange interaction, $z J=-0.00275 \mathrm{~cm}^{-1}$ and a ZFS parameter $B_{2}^{0} \theta_{2}=-0.5 \mathrm{~cm}^{-1}$ with $0.05 \mathrm{~cm}^{-1}$ constrain. The best fits yielded $g_{\text {iso }}=1.996(3)$. 


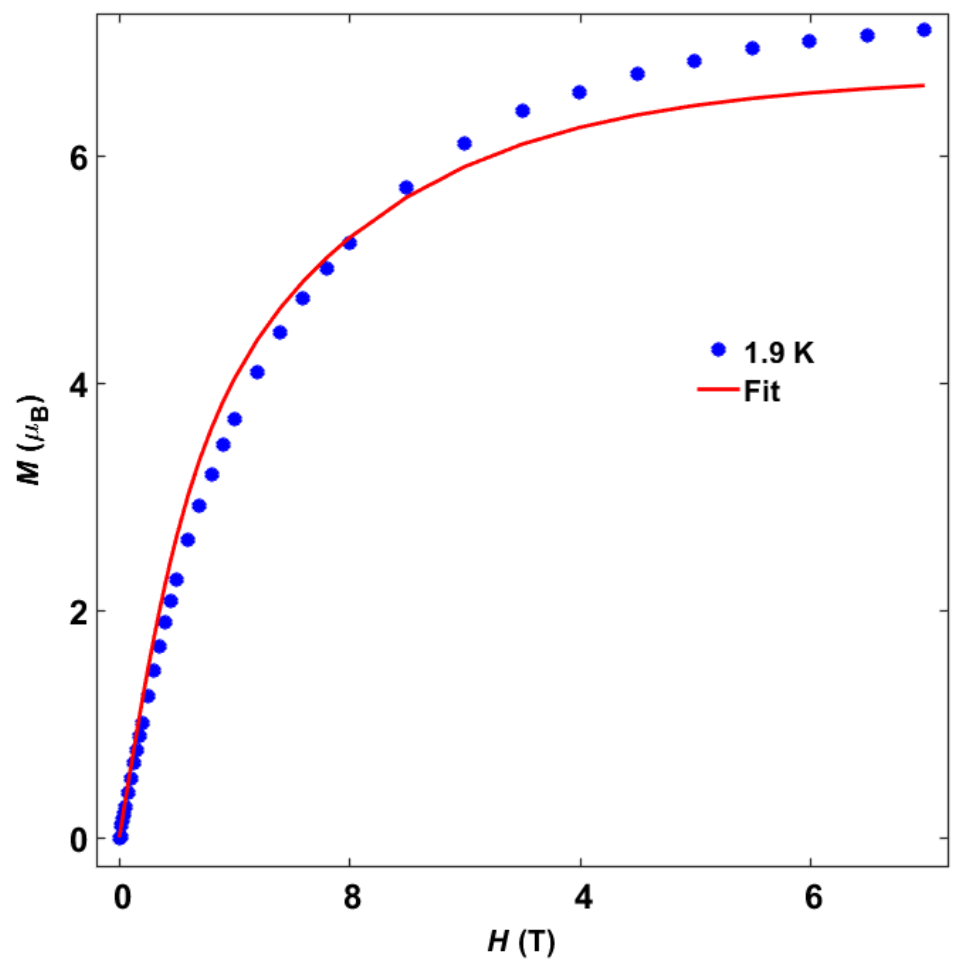

Figure S39. Plot of $M(H)$ (solid circles) with the best fits (solid lines) at $1.9 \mathrm{~K}$ for $\mathbf{3}_{\mathbf{G d}}$. The fitting parameters are as described in the caption of Figure S38. 


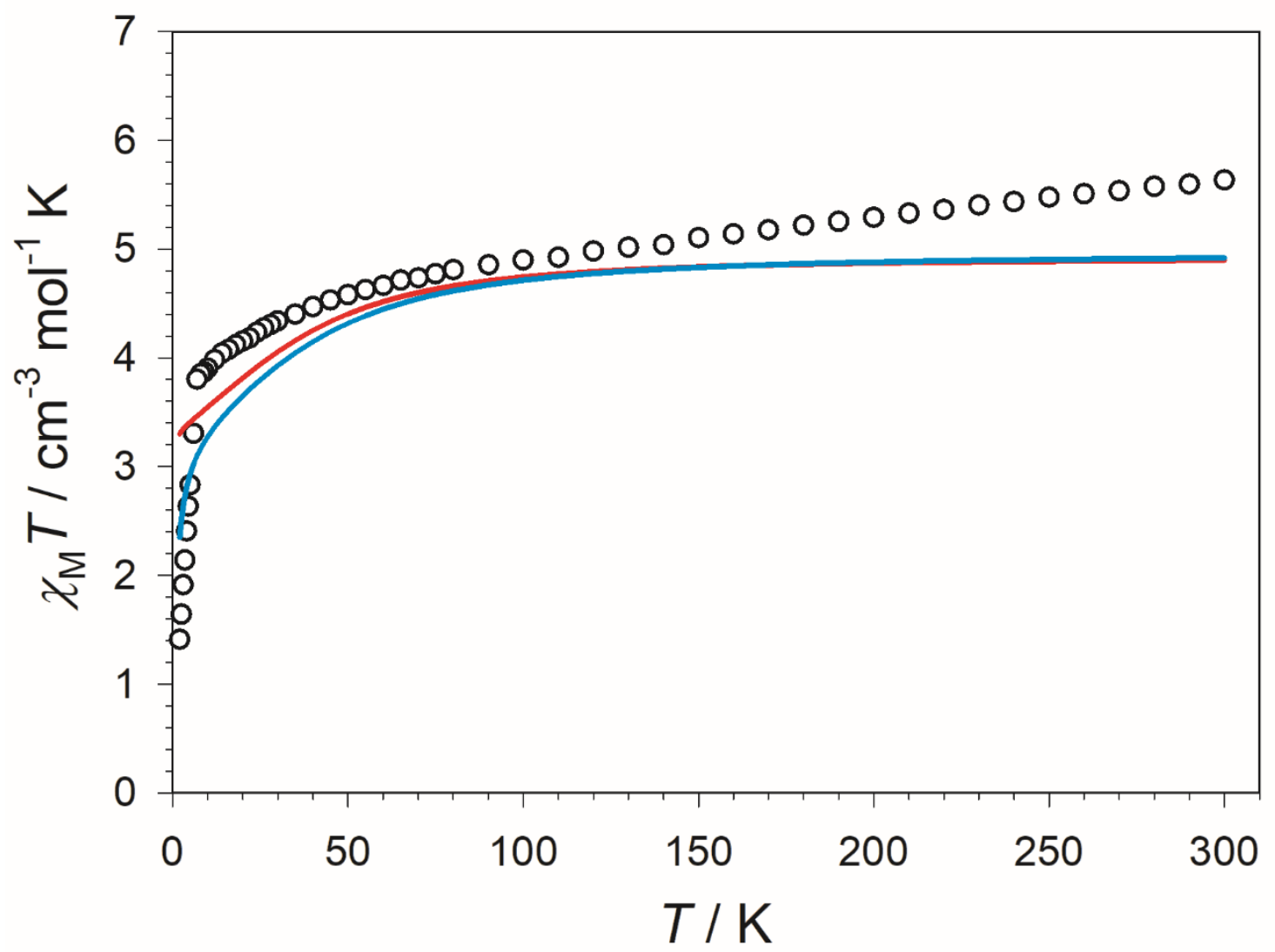

Figure S40. Plot of $\chi_{\mathrm{M}} T(T)$ (circles) in an applied field of $1 \mathrm{kOe}$ for $\mathbf{4}_{\mathrm{Y}}$. The attempted data fits (solid red and blue line) used the program PHI and applied the spin Hamiltonian, $\widehat{H}=D\left(\hat{S}_{Z}^{2}-\frac{1}{3} S(S+1)\right)+$ $E\left(\hat{S}_{x}^{2}-\hat{S}_{y}^{2}\right)+\mu_{B} \vec{g} \vec{B} \hat{S}+z J$. For the red fit, the following parameters were used: average anisotropic $g$-value $=2.561(4), D=-28.1(8) \mathrm{cm}^{-1}$ and $E=+0.012(0) \mathrm{cm}^{-1}$. For the blue fit, the following parameters were used: average anisotropic $g$-value $=2.572(4), D=-29.5(9) \mathrm{cm}^{-1}, E=-0.201(0) \mathrm{cm}^{-1}$ and $z J=-0.065(6) \mathrm{cm}^{-1}$. The deviation of the fits from the experimental data is likely to indicate strong spin-orbit coupling owing to mixing of a low-lying excited state with the ground state. 


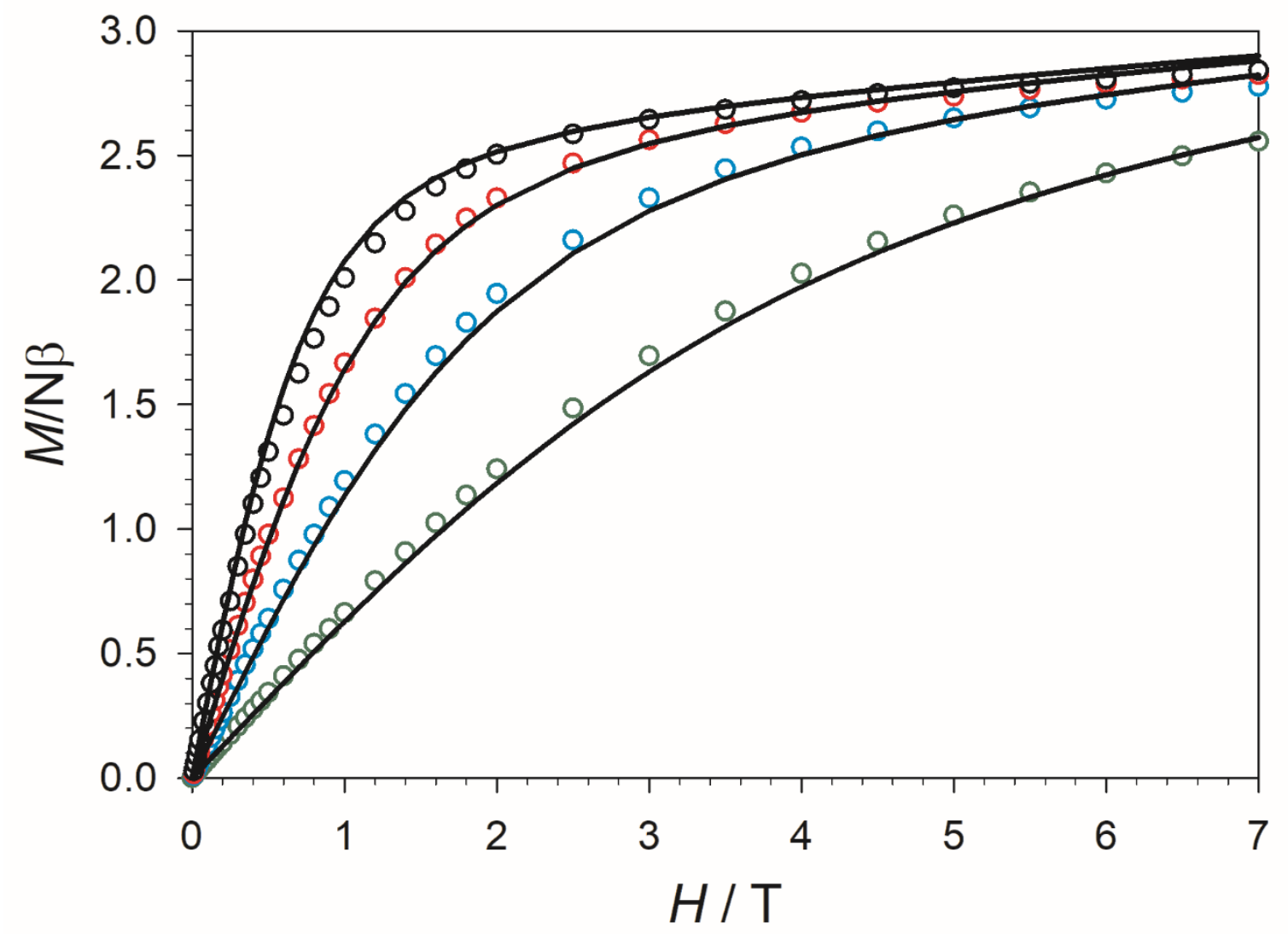

Figure S41. Plots of $M(H)$ at 1.9 (black), 3 (red), 5 (blue), and $10 \mathrm{~K}$ (green) for $\mathbf{4}_{\mathbf{Y}}$. The solid lines are fits of the data using the parameters stated in the caption to Figure S40. 


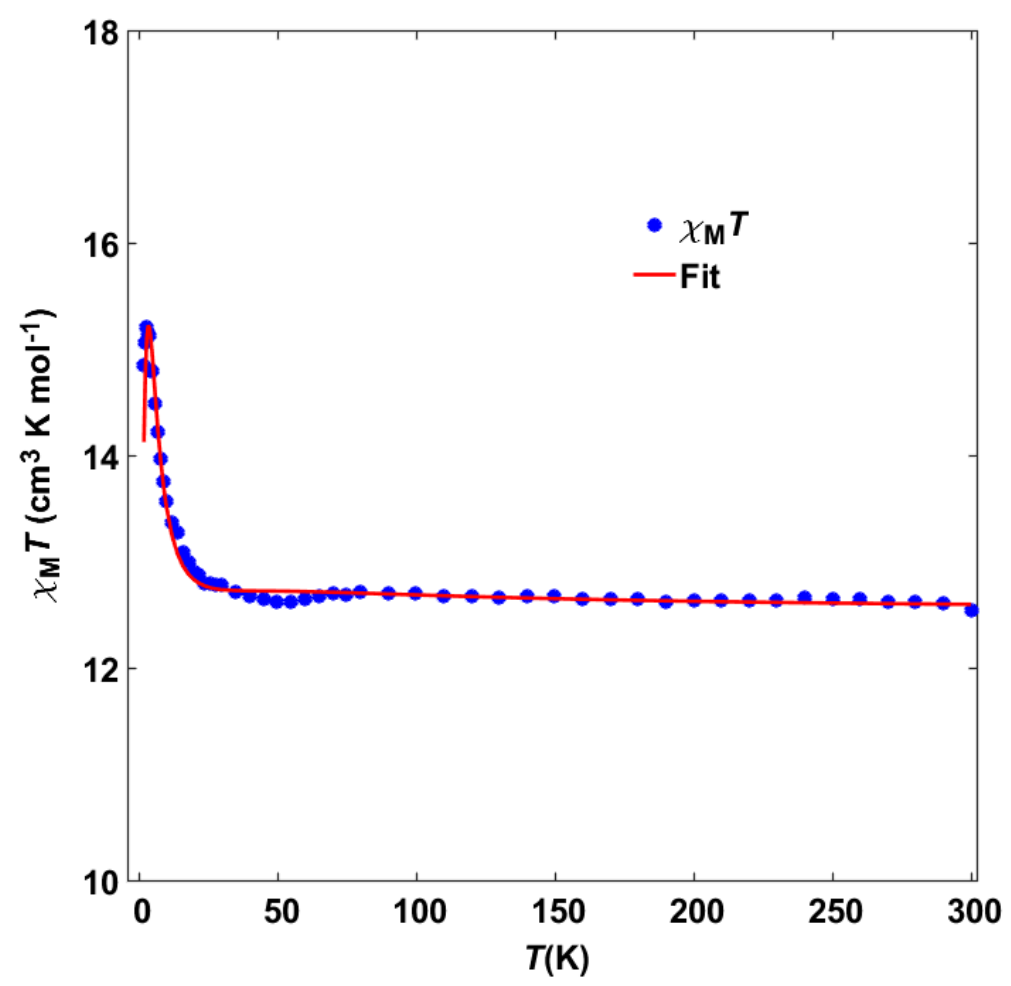

Figure S42. Plot of $\chi_{\mathrm{M}} T(T)$ (blue circles) with the best fit (solid red line) in an applied field of 1000 Oe $(0.1$ T) for $\mathbf{4}_{\mathbf{G d}}$. The spin Hamiltonian used for the fit is: $\widehat{H}=\sum_{i=F e} \sum_{k=2,4,6} \sum_{q=-k}^{k} B_{k i}^{q} \theta_{k} \widehat{O}_{k_{i}}^{q}+\mu_{B} \sum_{i=F e, G d}\left(\overrightarrow{\hat{S}}_{i} \cdot \overline{\bar{g}}_{l}\right) \cdot \vec{B}-2\left(\overrightarrow{\hat{S}}_{F e} \cdot \overline{\bar{J}}_{F e G d} \cdot \overrightarrow{\hat{S}}_{G d}\right)$, where $\overline{\bar{J}}_{F e G d}$ is the exchange coupling constant and the other symbols are as described above. The data were fitted with a meanfield intermolecular super-exchange interaction $z J=-0.005 \mathrm{~cm}^{-1}$, a ZFS parameter $B_{2}^{0} \theta_{2}=-0.278 \mathrm{~cm}^{-1}$ for gadolinium and $g_{\text {iso }}=2.00$ for gadolinium. The best fit yielded the following parameters: $D_{\mathrm{Fe}}=-18.28 \pm 0.93$ $\mathrm{cm}^{-1}, E=4.79 \pm 0.16 \mathrm{~cm}^{-1}$; an average g-factor of 2.488(8) and $\overline{\bar{J}}_{F e G d}=+0.251(5) \mathrm{cm}^{-1}$. 


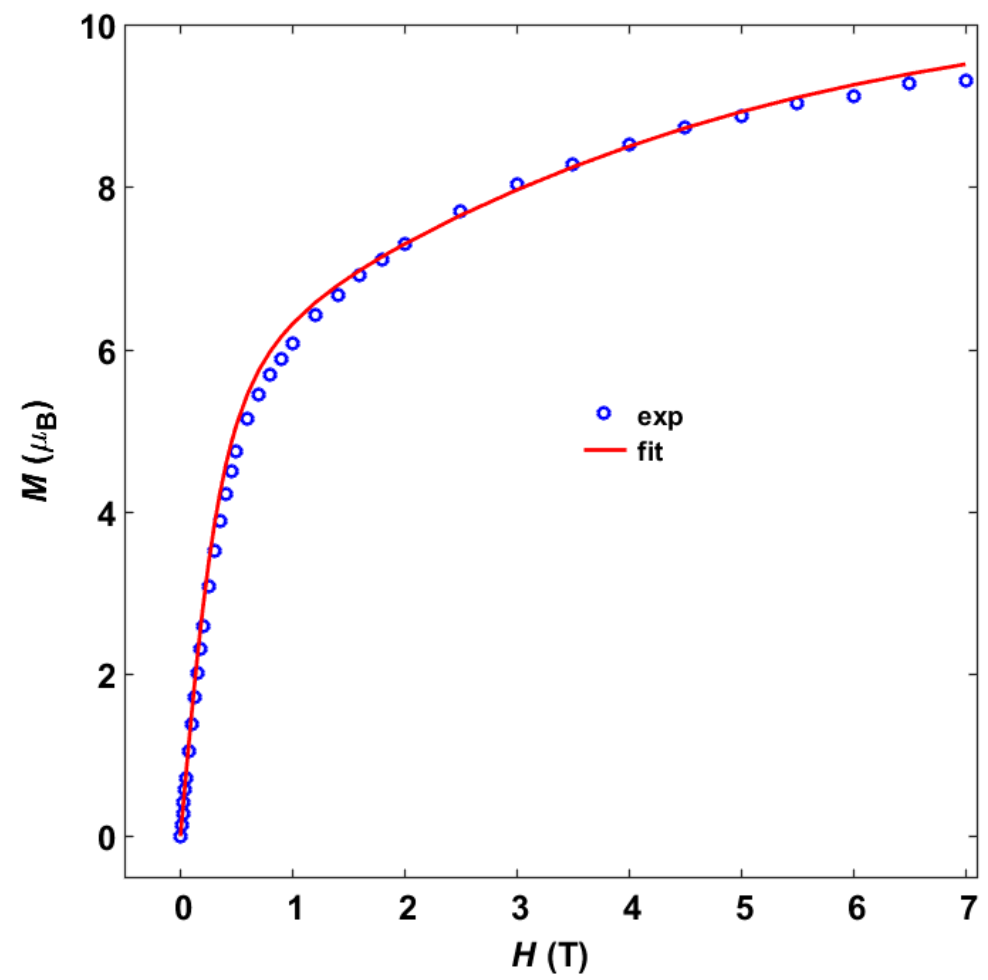

Figure S43. Plot of $M(H)$ (blue open circles) with the best fit (solid red line) at $1.9 \mathrm{~K}$ temperatures for $\mathbf{4}_{\mathrm{Gd}}$. The fitting parameters are as described in the caption of Figure S42. 


\section{References}

1. Evans, W. J.; Seibel, C. A.; Ziller, J. W. Unsolvated Lanthanide Metallocene Cations $\left[\left(\mathrm{C}_{5} \mathrm{Me}_{5}\right)_{2} \mathrm{Ln}\right]\left[\mathrm{BPh}_{4}\right]$ : Multiple Syntheses, Structural Characterization, and Reactivity Including the Formation of $\left(\mathrm{C}_{5} \mathrm{Me}_{5}\right)_{3} \mathrm{Nd}$. J. Am. Chem. Soc. 1998, 120, 6745-6752.

2. Cheng, M. Moore, D. R.; Reczek, J. J.; Chamberlain, B. M.; Lobkovsky, E. B.; Coates, G. W. SingleSite $\beta$-Diiminate Zinc Catalysts for the Alternating Copolymerization of $\mathrm{CO}_{2}$ and Epoxides: Catalyst Synthesis and Unprecedented Polymerization Activity. J. Am. Chem. Soc. 2001, 123, 8738-8749.

3. Connelly, N. G.; Gardner, C. Simple halogenonitrosyl anions of iron. J. Chem. Soc., Dalton Trans. 1976, $1525-1527$.

4. Tonzetich, Z. J.; Do, L. H.; Lippard, S. J. Dinitrosyl iron complexes relevant to Rieske cluster nitrosylation. J. Am. Chem. Soc. 2009, 131, 7964-7965.

5. Dolomanov, O. V.; Bourhis, L. J.; Gildea, R. J.; Howard, J. A. K.; Puschmann, H. OLEX2: a complete structure solution, refinement and analysis program. J. Appl. Crystallogr. 2009, 42, 339341.

6. Sheldrick, G. M. A short history of SHELX. Acta Crystallogr. Sect. A 2008, 64, 112-122.

7. Sheldrick, G. M. Crystal structure refinement with SHELXL. Acta Crystallogr. Sect. C 2015, 71, 3-8.

8. Bain, G. A.; Berry, J. F. Diamagnetic Corrections and Pascal's Constants. J. Chem. Educ. 2008, 85, 532 (2008).

9. Chilton, N. F.; Anderson, R. P.; Turner, L. D.; Soncini, A.; Murray, K. S. PHI: A powerful new program for the analysis of anisotropic monomeric and exchange-coupled polynuclear d- and f-block complexes. J. Comput. Chem. 2013, 34, 1164-1175. 